Published in final edited form as:

Neurosci Biobehav Rev. 2017 May ; 76(Pt A): 56-66. doi:10.1016/j.neubiorev.2016.12.033.

\title{
The endocannabinoid system as a target for novel anxiolytic drugs
}

\author{
Sachin Patel ${ }^{1,2,3,4}$, Mathew N. Hill ${ }^{5,6,7}$, Joseph F. Cheer ${ }^{8}$, Carsten T. Wotjak ${ }^{9}$, and Andrew \\ Holmes ${ }^{10,}{ }^{*}$ \\ ${ }^{1}$ Department of Psychiatry and Behavioral Sciences, Vanderbilt University Medical Center, \\ Nashville, USA \\ ${ }^{2}$ Vanderbilt Brain Institute, Vanderbilt University, Nashville, USA \\ ${ }^{3}$ Department of Molecular Physiology and Biophysics, Vanderbilt University School of Medicine, \\ Nashville, USA \\ ${ }^{4}$ Vanderbilt Kennedy Center for Human Development, Vanderbilt University Medical Center, \\ Nashville, USA \\ ${ }^{5}$ Hotchkiss Brain Institute, University of Calgary, Calgary, AB, Canada \\ ${ }^{6}$ Mathison Centre for Mental Health Research and Education, University of Calgary, Calgary, AB, \\ Canada \\ ${ }^{7}$ Departments of Cell Biology and Anatomy and Psychiatry, University of Calgary, Calgary, AB, \\ Canada
}

${ }^{8}$ Department of Anatomy and Neurobiology and Department of Psychiatry, University of Maryland School of Medicine, Baltimore, MD, USA

${ }^{9}$ Max Planck Institute of Psychiatry, Department of Stress Neurobiology \& Neurogenetics, Munich, Germany

${ }^{10}$ Laboratory of Behavioral and Genomic Neuroscience, National Institute on Alcohol Abuse and Alcoholism, National Institutes of Health, Bethesda, MD, USA

\section{Abstract}

The endocannabinoid (eCB) system has attracted attention for its role in various behavioral and brain functions, and as a therapeutic target in neuropsychiatric disease states, including anxiety disorders and other conditions resulting from dysfunctional responses to stress. In this minireview, we highlight components of the eCB system that offer potential 'druggable' targets for new anxiolytic medications, emphasizing some of the less well-discussed options. We discuss how selectively amplifying eCBs recruitment by interfering with eCB-degradation, via fatty acid amide

"Correspondence to: Andrew Holmes, PhD, Laboratory of Behavioral and Genomic Neuroscience, National Institute on Alcohol Abuse and Alcoholism, 5625 Fishers Lane Room 2N09, Rockville, MD, USA, 20852-9411, holmesan@mail.nih.gov, telephone: 301-402-3519.

Publisher's Disclaimer: This is a PDF file of an unedited manuscript that has been accepted for publication. As a service to our customers we are providing this early version of the manuscript. The manuscript will undergo copyediting, typesetting, and review of the resulting proof before it is published in its final citable form. Please note that during the production process errors may be discovered which could affect the content, and all legal disclaimers that apply to the journal pertain. 
hydrolase (FAAH) and monoacylglycerol lipase (MAGL), has been linked to reductions in anxiety-like behaviors in rodents and variation in human anxiety symptoms. We also discuss a non-canonical route to regulate $\mathrm{eCB}$ degradation that involves interfering with cyclooxygenase-2 (COX-2). Next, we discuss approaches to targeting eCB receptor-signaling in ways that do not involve the cannabinoid receptor subtype 1 (CB1R); by targeting the CB2R subtype and the transient receptor potential vanilloid type 1 (TRPV1). Finally, we review evidence that cannabidiol (CBD), while representing a less specific pharmacological approach, may be another way to modulate eCBs and interacting neurotransmitter systems to alleviate anxiety. Taken together, these various approaches provide a range of plausible paths to developing novel compounds that could prove useful for treating trauma-related and anxiety disorders.

\section{Keywords}

stress; fear; PTSD; COX-2; CB1 receptor; cannabis; dopamine; glucocorticoid; cortisol; amygdala; hippocampus; prefrontal cortex

\section{Introduction}

The eCB system and drugs that act on it continues to attract enormous attention from the scientific community and general public for its contribution to behavioral and brain functions, and for its potential as a therapeutic target across an array of peripheral and neuropsychiatric disease states. This trend is evident against a background of an ever developing understanding of the biology of cannabinoidergic actions, as well as public policy shifts towards greater acceptance of eCB-acting drugs for both recreational and medicinal purposes. In fact, interest in the therapeutic properties of the Cannabis sativa plant for all manner of ailments has a history that dates back millennia. In more recent times, the era of studying the plant for its medicinal properties can be traced to the identification of Delta-9-tetrahydrocannabinol (THC) and cannabidiol (CBD) as the plant's main active constituents and to the discovery of cannabinoid receptors and the endogenous substances (eCBs) acting on them, throughout the brain and body (Mechoulam and Parker, 2013).

The intervening half-century has seen important advances in medicinal exploitation of the eCB system, such that there are now a number of cannabinoid-acting compounds which are clinically approved to treat low appetite, nausea, vomiting, pain, and spasticity in cancer, AIDS and multiple-sclerosis, among other indications, with active research into developing drugs for a variety of other conditions. One area of particular interest to preclinical and clinical research on the eCB system is that relating to fear, anxiety and stress, and their associated psychiatric conditions, including the Anxiety Disorders and Posttraumatic Stress Disorder (PTSD, now diagnostically categorized as Trauma and Stress-related Conditions (DSM-5, 2013). These disorders represent by far the most common mental health problems, are often intertwined with other problems, such as alcohol and substance abuse. Unfortunately, they remain inadequately served by existing therapeutic, particularly pharmaceutical, options (Griebel and Holmes, 2013).

Several clinical observations have pointed to a link between stress-related disorders and cannabis use. For example, PTSD patients are more likely to exhibit cannabis dependence 
(Bonn-Miller et al., 2007; Kessler et al., 1995; Stewart et al., 1998), suggesting a degree of co-morbidity between PTSD and cannabis use. Epidemiology data such as these cannot clarify whether this link reflects shared etiological factors or cannabis use as a form of selfmedication, though it is worth noting that symptom severity correlates with the reported motivation to use cannabis in order to cope with emotional distress (Bonn-Miller et al., 2007). There is also preliminary data indicating that cannabis and related compounds can manage PTSD symptoms related to hyperarousal, anxiety responses to exteroceptive triggers and situational trauma-reminders (Bremner et al., 1996; Jetly et al., 2015). While these clinical observations need to be substantiated in larger, replicate populations, they do hint at stress and anxiety-alleviating effects of cannabis. In fact, cannabis has long been anecdotally noted for its ability to reduce anxiety and elevate mood in non-clinical populations and, in part because of this, eCBs have attracted considerable interest in recent years as a target for a new class of drugs to treat anxiety and stress-related conditions (Figure 1).

Comprehensive overviews of the large literature that has now built up around the potential clinical utility of eCB-targeting drugs can be found in previously published reviews from our groups and others (Gunduz-Cinar et al., 2013a; Lee et al., 2016; Micale et al., 2013; Morena et al., 2016b; Zlebnik and Cheer, 2016). Our aim in this mini-review is to highlight various components of the eCB system that offer 'druggable' targets for new anxiolytic and antidepressant medications, and to emphasize some of the less well-discussed options that nonetheless represent exciting possibilities for drug development (Figure 2). We begin with the intriguing concept of selectively amplifying recruitment of eCBs by interfering with the molecular machinery responsible for eCB-degradation. We discuss this approach with reference to the two canonical eCB hydrolyzing enzymes, fatty acid amide hydrolyze (FAAH) and monoacylglycerol lipase (MAGL), but also in terms of the less well-known mechanism mediated by cyclooxygenase-2 (COX-2). We then turn to eCB receptor-signaling with a view to drawing focus away from the vast literature on the cannabinoid receptor subtype 1 (CB1R) to other important receptors, most notably the transient receptor potential vanilloid receptor type 1 (TRPV1). Finally, we consider the nascent but interesting potential for modulating eCBs and interacting neurotransmitter systems via a major constituent of cannabis, cannabidiol (CBD).

\section{FAAH and MAGL: the Yin and the Yang of eCB hydrolysis}

While the biosynthesis of AEA has remained enigmatic for some time, the canonical pathways of AEA metabolism have been well described for over a decade. First characterized by Cravatt and colleagues as an enzyme which metabolizes oleamide (Cravatt et al., 1996), FAAH is a membrane-bound serine hydrolase which hydrolyzes a large class of fatty acid amides, including AEA. FAAH is primarily tethered to the membrane of the endoplasmic reticulum and is widely distributed throughout the brain, with prominent expression in the post-synaptic compartment of large pyramidal-like neurons (Gulyas et al., 2004; Thomas et al., 1997; Tsou et al., 1998). As genetic or pharmacological inactivation of FAAH results in a dramatic elevation in tissue levels of AEA, but not 2-AG, FAAH is considered as the primary metabolic enzyme of AEA. 
It has been well established that inhibition of FAAH, and elevation of AEA signaling, can significantly attenuate behavioral indices of fear and anxiety-related behavior in rodents. Following the characterization of the first relatively selective FAAH inhibitor, URB597, Piomelli's group established over a decade ago that inhibition of AEA hydrolysis produces anxiolytic-like effects in rats (Kathuria et al., 2003). Follow-up studies over the following several years demonstrated that there was an intriguing degree of specificity to these effects, such that gene deletion or selective pharmacological inhibition of FAAH, produced anxiolytic-like effects more reliably under conditions of high environmental aversiveness (Bluett et al., 2014; Carnevali et al., 2015; Gray et al., 2015; Haller et al., 2014; Haller et al., 2009; Hill et al., 2013b; Lomazzo et al., 2015; Naidu et al., 2007; Patel and Hillard, 2006; Rossi et al., 2010).

While a mechanistic explanation of why FAAH inhibition only exerts anxiolytic effects under highly aversive conditions remains elusive, the current working model posits that rather than directly producing frank anxiolytic-like effects, AEA signaling acts to restore homeostasis in anxiety-mediating circuits following stress-challenge. Specifically, under conditions of stress, FAAH activity has been found to be rapidly increased in brain regions regulating anxiety, such as the amygdala, with a concomitant reduction in the signaling pool of AEA (Bluett et al., 2014; Gray et al., 2015; Hill et al., 2013b; Patel et al., 2005; Rademacher et al., 2008). Accordingly, it appears that the reduction in AEA signaling in response to aversive environmental conditions acts to promote the development of an anxiety-like state, whereas inhibition of FAAH, and resultant potentiation of AEA signaling, acts to normalize AEA signaling and produce an associated reduction in anxiety-like behavior (for further discussion, see Gunduz-Cinar et al., 2013a; Morena et al., 2016b). From a therapeutic standpoint, the potential for increasing AEA, via FAAH inhibition, to preferentially modulate states of high anxiety could provide a therapeutic approach that selectively targets pathological forms of anxiety, without attendant side-effects (e.g., cognitive impairment, abuse-liability) that characterize many conventional anxiolytics.

The translational relevance of FAAH/AEA signaling to anxiety in humans is finding support from a variety of sources. Firstly, a number of studies have detected reduced levels of AEA in patients suffering from stress-related psychiatric illnesses, including major depression (Hill et al., 2009) and PTSD (Neumeister et al., 2013). Across individual patients, relatively low circulating levels of AEA correlate with higher scores on measures of anxiety in major depression (Hill et al., 2008) and the degree of intrusive symptoms in PTSD (Hill et al., 2013a). Secondly, a genetic variant in the human $F A A H$ gene has been identified that destabilizes FAAH protein, reduces FAAH-mediated AEA hydrolysis and enhances AEA signaling (Boileau et al., 2015; Chiang et al., 2004; Cravatt et al., 2001; Dincheva et al., 2015; Sipe et al., 2002; Sipe et al., 2010). This polymorphism (385A allele; rs324420) has been repeatedly associated with reduced indices of trait anxiety, as well as enhanced corticoamygdala connectivity and reduced activation and accelerated habituation of amygdala blood-oxygen-level dependent (BOLD) responses to threat cues (Demers et al., 2016; Dincheva et al., 2015; Gee et al., 2016; Gunduz-Cinar et al., 2013b; Hariri et al., 2009). 
These epidemiological and genetic data indicate that genetically-driven augmentation of AEA signaling confers a phenotype of reduced anxiety and propose a plausible neural basis for this influence. Indeed a key role for the amygdala would be entirely consistent with rodent studies that identify the basolateral amygdala as a critical locus in FAAH-mediated regulation of fear and anxiety-like behavior (Dincheva et al., 2015; Gunduz-Cinar et al., 2013b; Gunduz Cinar et al., 2015). Taken together, these convergent lines of human and rodent data evidence strengthen the case for examining FAAH inhibition as a tractable approach to alleviating anxiety and a number of pharmaceutical companies have been actively engaged in clinical trials that will testing the viability of this mechanism.

While a substantive body of evidence has amassed on the link between AEA signaling and anxiety, much less is currently known about 2-AG. Unlike AEA, however, the enzymatic cascades involved in both the biosynthesis and degradation of 2-AG are both relatively well characterized, with diacylglycerol lipase (DAGL) being the primary enzyme involved in synthesis, and MAGL being the primary enzyme involved in hydrolysis of 2-AG. Moreover, chronic unpredictable stressors have been shown to impair 2-AG signaling (Hill et al., 2005; Zhang et al., 2015) and selective inhibitors of MAGL have been developed and examined for their potential anxiety-related effects. The work that has been conducted to date has revealed that augmentation of 2-AG signaling through MAGL inhibition produces anxiolytic-like effects that, similar to the effects of FAAH inhibitors, are particularly prominent or entirely restricted to conditions of high environmental aversiveness - possibly reflecting the ondemand synthesis of 2-AG that is augmented by exposure to stress (Aliczki et al., 2012; Aliczki et al., 2013; Busquets-Garcia et al., 2011; Sciolino et al., 2011; Sumislawski et al., 2011; Zhang et al., 2015). However, there are some reports that MAGL inhibitors fail to affect anxiety-like behavior (Lomazzo et al., 2015) and that heightened emotional arousal can impair anxiolytic-like effects of MAGL inhibitors administered directly into the basolateral amygdala (Morena et al., 2016a). Further complicating the picture, MAGL inhibition has been found to disrupt, rather than promote, initial fear extinction acquisition (Hartley et al., 2016) and augment fear expression via 2-AG-mediated agonism of CB1R on GABAergic neurons (Llorente-Berzal et al., 2015).

In an illustrative example of the effects of MAGL inhibition, mice which develop a pathological-like form of anxiety-like behavior following repeated social defeat stress, were found to exhibit deficient 2-AG mediated plasticity in the nucleus accumbens and that administration of a MAGL inhibitor can normalize this behavioral phenotype as well as 2AG mediated synaptic plasticity in the nucleus accumbens (Bosch-Bouju et al., 2016). Conversely, in mice with genetic deletion of DALG and reductions in 2-AG signaling, increases in anxiety-like behavior are evident (Jenniches et al., 2016; Shonesy et al., 2014). Collectively, this indicates that 2-AG signaling is also a regulator of emotional behavior, whereby amplification of 2-AG signaling can attenuate anxiety-related readouts, particularly after exposure to stressful stimuli.

What then, if any, is the link between 2-AG, MAGL and stress relevant readouts in humans? While functional variants in the human MAGL gene have yet to be identified, two independent studies have now both reported that 2-AG levels are reduced in individuals with major depression (Hill et al., 2008; Hill et al., 2009) and another study found that low 
circulating 2-AG levels predict rates of depression after cardiac surgery (Hauer et al., 2012).

Reduced circulating 2-AG has also been found in patients with PTSD (Hill et al., 2013a) (though for the opposite effect, see Hauer et al., 2013). Finally, a recent study found that healthy volunteers exposed to chronic stressors exhibited progressively diminished circulating 2-AG levels, which correlated with the onset of reductions in measures of positive emotion (Yi et al., 2016).

Thus, there is emerging support for a relationship between 2-AG and stress-related indices in humans, as well as rodents, suggesting MAGL inhibition may be another therapeutic avenue for the treatment of anxiety disorders and other conditions associated with adverse responses to stressors. Enthusiasm for this mechanism is tempered somewhat by the ability of chronic, high-dose MAGL inhibition to desensitize the CB1R and produce a phenotype that is more akin to CB1R antagonism than agonism (Schlosburg et al., 2010; Schlosburg et al., 2014). Although CB1R desensitization is not seen at lower doses of MAGL inhibitors (Feliszek et al., 2016; Kinsey et al., 2013), the parameters and kinetics by which MAGL inhibition can regulate 2-AG signaling and CB1R efficacy clearly remains an important issue to be resolved before moving forward clinically with this target.

\section{COX-2: an alternate route to $\mathrm{eCB}$ degradation}

While FAAH and MAGL represent canonical inactivation mechanisms for AEA and 2-AG, respectively, several non-canonical eCB-inactivation pathways have recently been described, including lipoxygenase and p450 enzymes (Urquhart et al., 2015; Zelasko et al., 2015).

Here, we discuss emerging data that one of these pathways, COX-2, regulates eCB signaling at the synaptic, neurochemical and behavioral level in a manner that only partially overlaps with FAAH and MAGL inhibition (Hermanson et al., 2014; Hermanson et al., 2013), but nonetheless may have a role in the mediation of anxiety-like behavior and stress-responsivity (Gamble-George et al., 2016; Hermanson et al., 2013).

COX-2 is the immediate-early gene product of prostaglandin synthase-2 (PTGS2) expressed in an activity-dependent manner in many tissues, including neurons (Kaufmann et al., 1996). The role of COX-2 inhibition in regulating anxiety-like behaviors has in many cases been ascribed to reductions in pro-inflammatory prostaglandins. However, acute exogenous administration of prostaglandin E2 and D2 have been shown to have anxiolytic-like actions (Suzuki et al., 2011; Zhao et al., 2009), and prostaglandin E2 receptor null mutant mice exhibit reduced anxiety-like behavior (Savonenko et al., 2009). These data indicate a complex and currently incomplete picture of how COX-2 regulates anxiety-like processes; in addition, it seems likely that the effects and mechanisms of action COX-2 inhibition could depend on duration of treatment and endogenous inflammatory state.

With regards to the link between COX-2 and eCBs, COX-2 is primarily expressed postsynaptically and localizes to dendritic spines and dendrites in an expression pattern strikingly similar to that of FAAH (Cristino et al., 2008). COX-2 plays a critical role in generating prostaglandins via oxidation of arachidonic acid (AA), but has also been shown to utilize 2-AG and AEA as substrates to generate prostaglandin-glycerol (PG-G) and prostaglandin ethanolamide (PG-EA), respectively (Kozak et al., 2002; Kozak et al., 2000). 
Importantly, inhibition of COX-2 causes accumulation of eCBs as revealed, firstly, by increases in the tissue content of AEA and, to a lesser degree, 2-AG and, secondly, by enhanced eCB-mediated retrograde synaptic suppression - in the form of depolarizationinduced suppression of inhibition (DSI) and tonic eCB-suppression of glutamate release (Hermanson et al., 2013; Kim and Alger, 2004; Slanina and Schweitzer, 2005). Interestingly, recent work has also demonstrated P21-associated kinase enhances tonic AEA signaling at hippocampal GABAergic synapses by reducing synaptic COX-2 levels and subsequent decreases in COX-2-mediated inactivation of AEA signaling (Xia et al., 2016).

These findings indicate COX-2 regulation of eCB signaling represents an alternative mechanism to achieve eCB augmentation for therapeutic purposes, including in anxiety disorders. It is import to note in this regard that initial studies into COX-2 eCB-regulation have typically used traditional COX-2 inhibitors which, although selective for COX-2 over COX-1, inhibit the ability of COX-2 to oxidize AA, as well as eCBs, and thereby elevate levels of both substrates. This pharmacological property can be avoided by substrateselective COX-2 inhibitors (SSCIs), which block eCB oxidation without attendant actions on AA (Duggan et al., 2011; Hermanson et al., 2014; Windsor et al., 2012; Windsor et al., 2013). Utilizing both SSCIs and traditional COX-2 inhibitors, two preliminary studies have now examined the role of COX-2 in rodent anxiety-related behaviors. In the first report, systemic administration of the prototypic SSCI, LM-4131, was found to decrease mouse anxiety-like behavior in a range of assays (open field, light-dark exploration, elevated plusmaze) (Hermanson et al., 2013). Subsequent work showed that LM-4131, as well as two traditional COX-2 inhibitors, Lumiracoxib and Celecoxib, produced an anxiolytic-like effect in the novelty-induced hypophagia test in mice that had been subjected to acute foot-shock stress eight to twenty-four hours earlier (Gamble-George et al., 2016). Drug effects generalized across assays (elevated plus-maze, conditioned fear), sexes and ages, and were maintained under conditions of repeated stress or drug treatment - consistent with a robust anxiolytic-like action that was resistant to tolerance. Of further note, none of the drugs tested affected sucrose preference or tail-suspension test immobility, two measures associated more with antidepressant than anxiolytic efficacy.

These findings demonstrate that SSCIs and traditional COX-2 inhibitors alike, exert anxiolytic-like effects under a range of conditions, but are they functionally related to recruitment of the eCB system? The answer is probably not straightforward. On the one hand, the anxiolytic-like effects of LM-4131 were fully prevented (in the light-dark exploration test) by co-administration of a CB1R antagonist - consistent with eCBdependency of the COX-2 inhibitor's effects (Hermanson et al., 2013). On the other hand, the ability of LM-4131 and Lumiracoxib to decrease stress-induced measures of anxietyrelated behavior in the novelty-induced hypophagia test was not blocked by a CB1R antagonist or, for that matter, a TRPV1 or CB2R antagonist (Gamble-George et al., 2016). By contrast, the effects of LM-4131 could be prevented by administration of the smallconductance calcium activated (SK) potassium channel blocker, Apamin, and were mimicked by administration of the SK channel activator 1-EBIO (Gamble-George et al., 2016). Taken together, these preliminary findings suggest that under unstressed conditions, COX-2 inhibitors exert anxiolytic-like effects via CB1R-mediated eCB signaling but, 
following exposure to stress, these effects become uncoupled from this canonical mechanism of action.

This may be not end the story, however, because SK may itself be a molecular target of AEA (Wang et al., 2011). Furthermore, blocking COX-2 will limit the production of the active oxidative metabolites of AEA (prostaglandin-Gs) and 2-AG (prostaglandin-EAs), that are posited to exert their own effects at as yet to be determined receptors (Hu et al., 2008; Sang et al., 2006; Yang and Chen, 2008). This raises the intriguing possibility that the aforementioned anti-anxiety/anti-stress properties of AEA may, under certain conditions, be in part signaled through SK and other non-CB1R signaling pathways that COX-2 inhibitors access. While the research into this and other anxiety-related facets of COX-2 remains at an early stage, the observations to date encourage further investigation. And looking beyond the preclinical research, the question of whether COX-2 inhibition could represent a plausible approach to treating anxiety disorders is essentially untouched. Clinical investigation of the potential anxiolytic efficacy of traditional COX-2 inhibitors could proceed relatively rapidly, however, in view of the fact that Lumiracoxib and Celecoxib are currently approved as antiinflammatory medications.

\section{eCB receptors: vive la difference!}

$\mathrm{CB} 1 \mathrm{R}$ is the most prominent $\mathrm{eCB}$ binding site in the brain. The receptor is prominently expressed in various neuronal subpopulations, but also in astroglia and intracellular organelles, such as mitochondria (Busquets-Garcia et al., 2015). The latter classes of CB1R are particularly interesting in view of recent evidence for glial (Han et al., 2012) and mitochondrial CB1R (Hebert-Chatelain et al., 2016) in eCB-mediated mnemonic processes, together with a known role for astrocytes (Oliveira et al., 2015) and mitochondria (Manji et al., 2012) in stress- and anxiety-related processes. But looking beyond the CB1R, eCBs exert actions at a number of other, less prominent sites, including the CB2R and TRPV1 (Figure 3), either one of which could conceivably be involved in anxiety.

For some time, the CB2R was thought to be confined to immune cells and absent from the central nervous system (CNS) (Atwood et al., 2012; Fernandez-Ruiz et al., 2007; Parolaro, 1999), but this was later found to be questionable given the lack of specificity of the antibodies used (Ashton, 2012; Baek et al., 2013). Whether mediated via CB2R in the brain or periphery, ectopic genetic overexpression CB2R in mice (Racz et al., 2008) may mitigate behavioral reactions to chronic stress (Garcia-Gutierrez et al., 2010). Also of note are studies showing that genetic and pharmacological manipulations of CB2R function in rodents alters social interaction and aggression (Rodriguez-Arias et al., 2015), inhibitory avoidance learning (Garcia-Gutierrez et al., 2013; Ortega-Alvaro et al., 2011) and prepulse inhibition of the startle response (Ishiguro et al., 2010; Ortega-Alvaro et al., 2011). A potential link between variants in the human $C N R 2$ and major depression (Onaivi et al., 2008) has also been proposed. One hypothesis is that, given the role of the immune system in the etiology of various psychiatric diseases (Hodes et al., 2015; Yirmiya et al., 2015), CB2Rs expressed on immune cells, specifically microglia (Boorman et al., 2016), may underlie behavioral effects of CB2R manipulations. A recently generated conditional CB2R mutant mouse 
(Stempel et al., 2016) will serve to test this hypothesis by selectively deleting CB2R on microglia or neurons.

As was the case for CB2R, CNS expression of the non-selective cation channel TRPV1 had been disputed for some time. Mouse reporter lines generated to visualize TRPV1 found distinct and sparely distribution of TRPV1-positive neurons in anxiety-mediating brain areas including the periaqueductal grey (PAG), hypothalamus and hippocampus (Cavanaugh et al., 2011). However, functional expression may be underestimated if TRPV1 is expressed post and presynaptically (Aguiar et al., 2014) and acts far away from its synthesis sites (Gutierrez-Rodriguez et al., 2016; Ruehle et al., 2013). Indeed, there are additional reports of TRPV1 expression in the bed nucleus of the stria terminalis (BNST) (Puente et al., 2011), hippocampal dentate gyrus (Canduela et al., 2015; Lee et al., 2015; Puente et al., 2015) and hippocampal CA1 region (Lee et al., 2015) in postsynaptic terminals of both inhibitory (Canduela et al., 2015; Lee et al., 2015) and excitatory synapses (Puente et al., 2011; Puente et al., 2015). There is also evidence of presynaptic expression of TRPV1 in the nucleus tractus solitarus and PAG (Kawahara et al., 2011).

Consistent with its expression in anxiety-related regions of the brain, there is growing indication that TRPV1 acts as a ionotropic counterpart to the CB1R resulting in the promotion of fear- and anxiety-related responses in rodents (Aguiar et al., 2014; Casarotto et al., 2012; Marsch et al., 2007; Moreira et al., 2012; Terzian et al., 2009; Uliana et al., 2016). One scenario is that anxiety-related behaviors result from a balance between eCB-mediated inhibition (via CB1R) and excitation (via TRPV1) of anxiety-mediating circuits that, when operating correctly, serves as a system for switching between passive (e.g., freezing) and active (e.g., escape) behavioral responses based on the proximity of threat (Almeida-Santos et al., 2013; Casarotto et al., 2012). However, dysregulation of this TRPV1/CB1R balance could result in excessive anxiety and deficient stress-coping. Clarifying this issue requires careful analyses of behavior in preclinical assays in view of the contribution of brain and peripheral TRPV1 in motor behaviors and vegetative functions (Garami et al., 2011; Hudson et al., 2016).

Another key issue is the upstream mechanism(s) that generate signaling through TRPV1 to affect anxiety-related behaviors. One plausible route, given the extensive literate reviewed above, may be through AEA, which serves as full agonist at both CB1R and TRPV1 albeit with different affinity (Zygmunt et al., 1999). Postsynaptically-released AEA would bind presynaptically- and postsynaptically-located TRPV1 in a retrograde and anterograde manner, respectively. In addition, in view of the potential for AEA to be synthesized presynaptically (given the presynaptic presence of the rate-limiting AEA-synthesizing enzyme, NAPE-PLD) (Nyilas et al., 2008), AEA of presynaptic origin could also bind presynaptic TRPV1 (Puente et al., 2011). To help dissect these alternate modes of AEAmediated TRPV1 signaling in anxiety, future studies will benefit from the availability of photoswitchable TRPV1 agonists and antagonists (Frank et al., 2015; Stein et al., 2013), short-hairpin RNAs to downregulate TRPV1 in a temporally and spatially restricted manner (Hirai et al., 2014) and conditional TRPV1 null mutants (pending). 
There are then important issues to address regarding the suitability of TRPV1-targeting drugs for clinical use in anxiety disorders. As the available evidence suggests that effects at TRPV1 appear to be in opposition to the (anti-anxiety-like) behavioral actions exerted through CB1R (Kawahara et al., 2011), one avenue might be to develop compounds that block TRPV1 and at the same time inhibit FAAH (to stimulate CB1R), such that elevations in AEA and signaling at CB1R is not offset by TRPV1 activation. N-arachidonoyl-serotonin (AA-5-HT) may be a useful example of such a dual mode of action that can guide work in this area (Micale et al., 2009; Navarria et al., 2014).

\section{CBD: the other THC}

An issue that complicates the potential therapeutic utility of eCB-targeting drugs is that cannabis does not reliably reduce anxiety and can even induce anxiety in normals and increase symptom severity in PTSD patients (Cougle et al., 2011). These variable effects appear to be highly dependent on the individual and the context the drug is taken, but yet remain poorly understood. Some researchers have attributed this to a downregulation of the eCB signaling system (Hirvonen et al., 2012), resulting in tolerance to the drug's antianxiety effects and, in some cases, an unmasking of pro-anxiety properties. An alternative, though not necessarily mutually exclusive, view is that the anxiolytic effects of cannabis depend upon the neurobiological interplay or ratiometric relationship between the two major phytocannabinoids found in the cannabis plant, THC and CBD. There remains a relative dearth of data examining the anxiety-related actions of CBD and a lack of knowledge about how CBD's effects are modulated by THC and the other phytocannabinoids found in cannabis - a pharmacological phenomenon referred to as the entourage effect.

However, several clinical reports have documented anxiolytic effects of CBD. For instance CBD reverses THC-induced anxiety (Zuardi et al., 1982) and glossophobia (fear of public speaking) (Bergamaschi et al., 2011; Crippa et al., 2004; Zuardi et al., 1993), and attenuates regional brain reactivity to fear-inducing stimuli in functional magnetic resonance imaging studies (Crippa et al., 2004; Fusar-Poli et al., 2010). The rodent literature arising from studies by Guimãraes and colleagues and other groups aligns quite well with these data. Systemic administration of CBD in rats exerts anxiolytic-like effects in the elevated plusmaze (Campos and Guimaraes, 2008; Campos et al., 2013b; Gomes et al., 2012; Guimaraes et al., 1990; Onaivi et al., 1990; Schiavon et al., 2016), Vogel conflict test (Campos and Guimaraes, 2008; Gomes et al., 2012; Moreira et al., 2006) and marble-burying test (in mice) (Casarotto et al., 2010), and reduces conditioned contextual fear (Resstel et al., 2006). Similar effects can be produced by microinjections of CBD into brain regions including the central nucleus of the amygdala (Hsiao et al., 2012), bed nucleus of the stria terminalis (BNST) (Gomes et al. 2010, 2012), and dorsal periaqueductal gray (dPAG) (Campos and Guimaraes 2008). The anti-anxiety properties of CBD do, however, appear to be dosedependent, with efficacy inversely correlated with dose (Guimaraes et al., 1990).

The mechanisms by which CBD confers its anxiolytic effects remain undetermined. CBD exhibits little to no orthosteric binding potential at $\mathrm{CB} 1 \mathrm{R}$ or $\mathrm{CB} 2 \mathrm{R}$ and can, under certain conditions, effectively antagonize the receptors even at low $\mathrm{nM}$ concentrations (Russo, 2011). As such, CBD has been termed a negative allosteric modulator at CB1R (Laprairie et 
al., 2015), a pharmacological property that might explain how CBD could attenuate several effects of THC, which itself acts as a CB1R partial agonist. In addition, CBD is a TRPV1 agonist with an affinity for the receptor similar to the irritant substance found in chili peppers, capsaicin (Bisogno et al., 2001), but lacks the pain-inducing properties of capsaicin and can potently desensitize TRPV1 even at low concentrations (Bisogno et al., 2001).

Given the aforementioned evidence implicating TRPV1 in the regulation of fear and anxiety, it will be of significant interest to examine the potential interactions between CBD and this receptor.

Beyond its actions at CB1R and TRPV1, CBD can actually affect signaling at a staggering number of pathways that could feasibly impact anxiety (Russo, 2016). For instance, CBD is an inhibitor of adenosine uptake and facilitation of adenosine signaling produces anxiolyticlike effects (Carrier et al., 2006). Another CBD-target of particular interest is the 5-

hydroxytryptamine $1 \mathrm{~A}$ receptor subtype (5-HT1A-R) - a metabotropic seven-transmembrane receptor, negatively-coupled to $\mathrm{G}$ proteins (Gi/Go), that has been the subject of interest for its anti-anxiety properties for decades (Holmes, 2008). CBD rapidly increases extracellular serotonin and glutamate levels in mouse cortex (Llado-Pelfort et al., 2012) and amplifies 5HT1A-R-mediated inhibition of GABAergic interneurons (Santana et al., 2004) to disinhibit glutamatergic output in downstream structures (Llado-Pelfort et al., 2012). This in turn is likely to augment activity at 5-HT neurons in the dorsal raphe nucleus (DRN) (Llado-Pelfort et al., 2012), enhancing 5-HT in corticolimbic projection fields to complete a system-level functional loop. Finally, there are also potential effects of CBD activation of 5-HT1A-Rs located on interneurons proximal to the DRN, as well as effects on 5-HT1A-Rs expressed on DRN 5-HT neurons themselves. Thus, the interplay between CBD and the 5-HT system is likely to be highly complex and to occur at multiple levels.

Nevertheless, there is initial evidence supporting a functional connection between CBD and the 5-HT1A-R in regulating anxiety-like behavior. The anxiolytic-like effects produced by CBD injections into the rat infralimbic (Marinho et al., 2015) or prelimbic (Fogaca et al., 2014) cortices, BNST (Gomes et al., 2013; Gomes et al., 2012; Gomes et al., 2011) and dPAG (Campos et al., 2013a) are attenuated by concomitant 5-HT1A-R antagonism. One potential explanation for this interaction is that $\mathrm{CBD}$ could work as a positive allosteric enhancer of 5-HT1A-R. This would mean that for CBD to be fully effective as an anxiolytic there would need to be basal 5-HT1A-R occupancy (Rock et al., 2012). This is notable because 5-HT1A-R agonists, such as Buspirone, display also anxiolytic-like properties in assorted preclinical assays (e.g., Roncon et al., 2013; Saito et al., 2013; Zhou et al., 2014) and are clinically prescribed for various Anxiety Disorders, with reasonable response rates (Blessing et al., 2015; Chessick et al., 2006). Thus, one could envision a treatment strategy entailing the use of CBD as an adjunct that augment Buspirone efficacy via the two drugs additive or synergistic action at the 5-HT1A-R. An added benefit would be that the limited psychoactive profile of CBD, as compared to, for instance, THC, should produce fewer sideeffects. The next step will be to begin testing these predictions in the clinic and parallel preclinical assays. 


\section{Concluding remarks}

There is growing interest in the $\mathrm{eCB}$ system as a target for anxiety, trauma and stress-related disorders based on a burgeoning preclinical and clinical literature that supports a relationship between eCBs and fear, anxiety and stress. In the current mini-review, we have sought to highlight some of the main pathways to exploiting the eCB system as a means of generating novel pharmacotherapeutics for these disorders. These include the notion of augmenting the on-demand recruitment of AEA and 2-AG, either by inhibiting the hydrolyzing enzymes, fatty acid amide hydrolyze (FAAH) and monoacylglycerol lipase (MAGL), or by targeted inhibition of cyclooxygenase-2 (COX-2). Alternatively, blocking the activation of TRPV1 receptors, possibly in concert with the augmentation of AEA, could be an effective route to alleviating excessive anxiety and promoting stress-coping. Lastly, there is the possibility of utilizing the constituent of cannabis, $\mathrm{CBD}$, to treat anxiety and stress-related disorders, albeit via neural mechanisms that might be independent of eCB signaling. Further basic research together with well-designed clinical studies, over the coming years will determine how successfully these various promising approaches evolve into much needed medications.

\section{Acknowledgments}

S.P. is supported by NIH grants MH10743 and the Brain and Behavior Foundation. MNH is supported by a Tier II Canada Research Chair from the Canadian Institutes of Health Research (CIHR) and operating grant support from CIHR and the Natural Sciences and Engineering Research Council of Canada. J.F.C. is supported by NIH grant DA022340. C.W is supported by Max Planck Institute of Psychiatry. AH is supported by the NIAAA Intramural Research Program.

\section{References}

Aguiar DC, Moreira FA, Terzian AL, Fogaca MV, Lisboa SF, Wotjak CT, Guimaraes FS. Modulation of defensive behavior by Transient Receptor Potential Vanilloid Type-1 (TRPV1) Channels. Neuroscience and biobehavioral reviews. 2014

Aliczki M, Balogh Z, Tulogdi A, Haller J. The temporal dynamics of the effects of monoacylglycerol lipase blockade on locomotion, anxiety, and body temperature. Behavioural pharmacology. 2012; 23:348-357. [PubMed: 22750842]

Aliczki M, Zelena D, Mikics E, Varga ZK, Pinter O, Bakos NV, Varga J, Haller J. Monoacylglycerol lipase inhibition-induced changes in plasma corticosterone levels, anxiety and locomotor activity in male CD1 mice. Hormones and behavior. 2013; 63:752-758. [PubMed: 23578952]

Almeida-Santos AF, Moreira FA, Guimaraes FS, Aguiar DC. Role of TRPV1 receptors on panic-like behaviors mediated by the dorsolateral periaqueductal gray in rats. Pharmacology, biochemistry, and behavior. 2013; 105:166-172.

Ashton JC. The use of knockout mice to test the specificity of antibodies for cannabinoid receptors. Hippocampus. 2012; 22:643-644. [PubMed: 21538668]

Atwood BK, Straiker A, Mackie K. CB(2): therapeutic target-in-waiting. Progress in neuropsychopharmacology \& biological psychiatry. 2012; 38:16-20. [PubMed: 22197668]

Baek JH, Darlington CL, Smith PF, Ashton JC. Antibody testing for brain immunohistochemistry: brain immunolabeling for the cannabinoid $\mathrm{CB}(2)$ receptor. Journal of neuroscience methods. 2013; 216:87-95. [PubMed: 23583232]

Bergamaschi MM, Queiroz RH, Chagas MH, de Oliveira DC, De Martinis BS, Kapczinski F, Quevedo J, Roesler R, Schroder N, Nardi AE, Martin-Santos R, Hallak JE, Zuardi AW, Crippa JA. Cannabidiol reduces the anxiety induced by simulated public speaking in treatment-naive social phobia patients. Neuropsychopharmacology. 2011; 36:1219-1226. [PubMed: 21307846]

Bisogno T, Hanus L, De Petrocellis L, Tchilibon S, Ponde DE, Brandi I, Moriello AS, Davis JB, Mechoulam R, Di Marzo V. Molecular targets for cannabidiol and its synthetic analogues: effect on 
vanilloid VR1 receptors and on the cellular uptake and enzymatic hydrolysis of anandamide. British journal of pharmacology. 2001; 134:845-852. [PubMed: 11606325]

Blessing EM, Steenkamp MM, Manzanares J, Marmar CR. Cannabidiol as a Potential Treatment for Anxiety Disorders. Neurotherapeutics. 2015; 12:825-836. [PubMed: 26341731]

Bluett RJ, Gamble-George JC, Hermanson DJ, Hartley ND, Marnett LJ, Patel S. Central anandamide deficiency predicts stress-induced anxiety: behavioral reversal through endocannabinoid augmentation. Translational psychiatry. 2014; 4:e408. [PubMed: 25004388]

Boileau I, Tyndale RF, Williams B, Mansouri E, Westwood DJ, Le Foll B, Rusjan PM, Mizrahi R, De Luca V, Zhou Q, Wilson AA, Houle S, Kish SJ, Tong J. The fatty acid amide hydrolase C385A variant affects brain binding of the positron emission tomography tracer [11C]CURB. Journal of cerebral blood flow and metabolism : official journal of the International Society of Cerebral Blood Flow and Metabolism. 2015; 35:1237-1240.

Bonn-Miller MO, Vujanovic AA, Feldner MT, Bernstein A, Zvolensky MJ. Posttraumatic stress symptom severity predicts marijuana use coping motives among traumatic event-exposed marijuana users. J Trauma Stress. 2007; 20:577-586. [PubMed: 17721963]

Boorman E, Zajkowska Z, Ahmed R, Pariante CM, Zunszain PA. Crosstalk between endocannabinoid and immune systems: a potential dysregulation in depression? Psychopharmacology. 2016; 233:1591-1604. [PubMed: 26483037]

Bosch-Bouju C, Larrieu T, Linders L, Manzoni OJ, Laye S. Endocannabinoid-Mediated Plasticity in Nucleus Accumbens Controls Vulnerability to Anxiety after Social Defeat Stress. Cell reports. 2016; 16:1237-1242. [PubMed: 27452462]

Bremner JD, Southwick SM, Darnell A, Charney DS. Chronic PTSD in Vietnam combat veterans: course of illness and substance abuse. Am J Psychiatry. 1996; 153:369-375. [PubMed: 8610824]

Busquets-Garcia A, Desprez T, Metna-Laurent M, Bellocchio L, Marsicano G, Soria-Gomez E. Dissecting the cannabinergic control of behavior: The where matters. BioEssays : news and reviews in molecular, cellular and developmental biology. 2015; 37:1215-1225.

Busquets-Garcia A, Puighermanal E, Pastor A, de la Torre R, Maldonado R, Ozaita A. Differential role of anandamide and 2-arachidonoylglycerol in memory and anxiety-like responses. Biological psychiatry. 2011; 70:479-486. [PubMed: 21684528]

Campos AC, de Paula Soares V, Carvalho MC, Ferreira FR, Vicente MA, Brandao ML, Zuardi AW, Zangrossi H Jr, Guimaraes FS. Involvement of serotonin-mediated neurotransmission in the dorsal periaqueductal gray matter on cannabidiol chronic effects in panic-like responses in rats. Psychopharmacology. 2013a; 226:13-24. [PubMed: 23007604]

Campos AC, Guimaraes FS. Involvement of 5HT1A receptors in the anxiolytic-like effects of cannabidiol injected into the dorsolateral periaqueductal gray of rats. Psychopharmacology. 2008; 199:223-230. [PubMed: 18446323]

Campos AC, Ortega Z, Palazuelos J, Fogaca MV, Aguiar DC, Diaz-Alonso J, Ortega-Gutierrez S, Vazquez-Villa H, Moreira FA, Guzman M, Galve-Roperh I, Guimaraes FS. The anxiolytic effect of cannabidiol on chronically stressed mice depends on hippocampal neurogenesis: involvement of the endocannabinoid system. The international journal of neuropsychopharmacology / official scientific journal of the Collegium Internationale Neuropsychopharmacologicum. 2013b; 16:14071419.

Canduela MJ, Mendizabal-Zubiaga J, Puente N, Reguero L, Elezgarai I, Ramos-Uriarte A, Gerrikagoitia I, Grandes P. Visualization by high resolution immunoelectron microscopy of the transient receptor potential vanilloid-1 at inhibitory synapses of the mouse dentate gyrus. PloS one. 2015; 10:e0119401. [PubMed: 25775089]

Carnevali L, Vacondio F, Rossi S, Callegari S, Macchi E, Spadoni G, Bedini A, Rivara S, Mor M, Sgoifo A. Antidepressant-like activity and cardioprotective effects of fatty acid amide hydrolase inhibitor URB694 in socially stressed Wistar Kyoto rats. European neuropsychopharmacology : the journal of the European College of Neuropsychopharmacology. 2015; 25:2157-2169. [PubMed: 26391492]

Carrier EJ, Auchampach JA, Hillard CJ. Inhibition of an equilibrative nucleoside transporter by cannabidiol: a mechanism of cannabinoid immunosuppression. Proceedings of the National Academy of Sciences of the United States of America. 2006; 103:7895-7900. [PubMed: 16672367] 
Casarotto PC, Gomes FV, Resstel LB, Guimaraes FS. Cannabidiol inhibitory effect on marble-burying behaviour: involvement of CB1 receptors. Behavioural pharmacology. 2010; 21:353-358. [PubMed: 20695034]

Casarotto PC, Terzian AL, Aguiar DC, Zangrossi H, Guimaraes FS, Wotjak CT, Moreira FA. Opposing roles for cannabinoid receptor type-1 $(\mathrm{CB}(1))$ and transient receptor potential vanilloid type-1 channel (TRPV1) on the modulation of panic-like responses in rats. Neuropsychopharmacology : official publication of the American College of Neuropsychopharmacology. 2012; 37:478-486. [PubMed: 21937980]

Cavanaugh DJ, Chesler AT, Jackson AC, Sigal YM, Yamanaka H, Grant R, O’Donnell D, Nicoll RA, Shah NM, Julius D, Basbaum AI. Trpv1 reporter mice reveal highly restricted brain distribution and functional expression in arteriolar smooth muscle cells. The Journal of neuroscience : the official journal of the Society for Neuroscience. 2011; 31:5067-5077. [PubMed: 21451044]

Chessick CA, Allen MH, Thase M, Batista Miralha da Cunha AB, Kapczinski FF, de Lima MS, dos Santos Souza JJ. Azapirones for generalized anxiety disorder. The Cochrane database of systematic reviews. 2006 CD006115.

Chiang KP, Gerber AL, Sipe JC, Cravatt BF. Reduced cellular expression and activity of the P129T mutant of human fatty acid amide hydrolase: evidence for a link between defects in the endocannabinoid system and problem drug use. Hum Mol Genet. 2004; 13:2113-2119. [PubMed: 15254019]

Cougle JR, Bonn-Miller MO, Vujanovic AA, Zvolensky MJ, Hawkins KA. Posttraumatic stress disorder and cannabis use in a nationally representative sample. Psychol Addict Behav. 2011; 25:554-558. [PubMed: 21480682]

Cravatt BF, Demarest K, Patricelli MP, Bracey MH, Giang DK, Martin BR, Lichtman AH. Supersensitivity to anandamide and enhanced endogenous cannabinoid signaling in mice lacking fatty acid amide hydrolase. Proceedings of the National Academy of Sciences of the United States of America. 2001; 98:9371-9376. [PubMed: 11470906]

Cravatt BF, Giang DK, Mayfield SP, Boger DL, Lerner RA, Gilula NB. Molecular characterization of an enzyme that degrades neuromodulatory fatty-acid amides. Nature. 1996; 384:83-87. [PubMed: 8900284]

Crippa JA, Zuardi AW, Garrido GE, Wichert-Ana L, Guarnieri R, Ferrari L, Azevedo-Marques PM, Hallak JE, McGuire PK, Filho Busatto G. Effects of cannabidiol (CBD) on regional cerebral blood flow. Neuropsychopharmacology. 2004; 29:417-426. [PubMed: 14583744]

Cristino L, Starowicz K, De Petrocellis L, Morishita J, Ueda N, Guglielmotti V, Di Marzo V. Immunohistochemical localization of anabolic and catabolic enzymes for anandamide and other putative endovanilloids in the hippocampus and cerebellar cortex of the mouse brain. Neuroscience. 2008; 151:955-968. [PubMed: 18248904]

Demers CH, Drabant Conley E, Bogdan R, Hariri AR. Interactions Between Anandamide and Corticotropin-Releasing Factor Signaling Modulate Human Amygdala Function and Risk for Anxiety Disorders: An Imaging Genetics Strategy for Modeling Molecular Interactions. Biological psychiatry. 2016; 80:356-362. [PubMed: 26923505]

Dincheva I, Drysdale AT, Hartley CA, Johnson DC, Jing D, King EC, Ra S, Gray JM, Yang R, DeGruccio AM, Huang C, Cravatt BF, Glatt CE, Hill MN, Casey BJ, Lee FS. FAAH genetic variation enhances fronto-amygdala function in mouse and human. Nature communications. 2015; 6:6395.

DSM-5. Diagnostic and Statistical Manual of Mental Disorders. Fourth. Washington, D.C.: APA Press; 2013.

Duggan KC, Hermanson DJ, Musee J, Prusakiewicz JJ, Scheib JL, Carter BD, Banerjee S, Oates JA, Marnett LJ. (R)-Profens are substrate-selective inhibitors of endocannabinoid oxygenation by COX-2. Nature chemical biology. 2011; 7:803-809. [PubMed: 22053353]

Feliszek M, Bindila L, Lutz B, Zimmer A, Bilkei-Gorzo A, Schlicker E. Lack of hippocampal CB1 receptor desensitization by Delta(9)-tetrahydrocannabinol in aged mice and by low doses of JZL 184. Naunyn-Schmiedeberg's archives of pharmacology. 2016; 389:603-612.

Fernandez-Ruiz J, Romero J, Velasco G, Tolon RM, Ramos JA, Guzman M. Cannabinoid CB2 receptor: a new target for controlling neural cell survival? Trends in pharmacological sciences. 2007; 28:39-45. [PubMed: 17141334] 
Fogaca MV, Reis FM, Campos AC, Guimaraes FS. Effects of intra-prelimbic prefrontal cortex injection of cannabidiol on anxiety-like behavior: involvement of 5HT1A receptors and previous stressful experience. European neuropsychopharmacology : the journal of the European College of Neuropsychopharmacology. 2014; 24:410-419. [PubMed: 24321837]

Frank JA, Moroni M, Moshourab R, Sumser M, Lewin GR, Trauner D. Photoswitchable fatty acids enable optical control of TRPV1. Nature communications. 2015; 6:7118.

Fusar-Poli P, Allen P, Bhattacharyya S, Crippa JA, Mechelli A, Borgwardt S, Martin-Santos R, Seal ML, O'Carrol C, Atakan Z, Zuardi AW, McGuire P. Modulation of effective connectivity during emotional processing by Delta 9-tetrahydrocannabinol and cannabidiol. Int J Neuropsychopharmacol. 2010; 13:421-432. [PubMed: 19775500]

Gamble-George JC, Baldi R, Halladay L, Kocharian A, Hartley N, Silva CG, Roberts H, Haymer A, Marnett LJ, Holmes A, Patel S. Cyclooxygenase-2 inhibition reduces stress-induced affective pathology. Elife. 2016; 5

Garami A, Pakai E, Oliveira DL, Steiner AA, Wanner SP, Almeida MC, Lesnikov VA, Gavva NR, Romanovsky AA. Thermoregulatory phenotype of the Trpv1 knockout mouse: thermoeffector dysbalance with hyperkinesis. The Journal of neuroscience : the official journal of the Society for Neuroscience. 2011; 31:1721-1733. [PubMed: 21289181]

Garcia-Gutierrez MS, Ortega-Alvaro A, Busquets-Garcia A, Perez-Ortiz JM, Caltana L, Ricatti MJ, Brusco A, Maldonado R, Manzanares J. Synaptic plasticity alterations associated with memory impairment induced by deletion of CB2 cannabinoid receptors. Neuropharmacology. 2013; 73:388-396. [PubMed: 23796670]

Garcia-Gutierrez MS, Perez-Ortiz JM, Gutierrez-Adan A, Manzanares J. Depression-resistant endophenotype in mice overexpressing cannabinoid $\mathrm{CB}(2)$ receptors. British journal of pharmacology. 2010; 160:1773-1784. [PubMed: 20649579]

Gee DG, Fetcho RN, Jing D, Li A, Glatt CE, Drysdale AT, Cohen AO, Dellarco DV, Yang RR, Dale AM, Jernigan TL, Lee FS, Casey BJ, Consortium P. Individual differences in frontolimbic circuitry and anxiety emerge with adolescent changes in endocannabinoid signaling across species. Proceedings of the National Academy of Sciences of the United States of America. 2016; 113:4500-4505. [PubMed: 27001846]

Gomes FV, Alves FH, Guimaraes FS, Correa FM, Resstel LB, Crestani CC. Cannabidiol administration into the bed nucleus of the stria terminalis alters cardiovascular responses induced by acute restraint stress through 5-HT(1)A receptor. European neuropsychopharmacology : the journal of the European College of Neuropsychopharmacology. 2013; 23:1096-1104. [PubMed: 23041353]

Gomes FV, Reis DG, Alves FH, Correa FM, Guimaraes FS, Resstel LB. Cannabidiol injected into the bed nucleus of the stria terminalis reduces the expression of contextual fear conditioning via 5HT1A receptors. Journal of psychopharmacology. 2012; 26:104-113. [PubMed: 21148020]

Gomes FV, Resstel LB, Guimaraes FS. The anxiolytic-like effects of cannabidiol injected into the bed nucleus of the stria terminalis are mediated by 5-HT1A receptors. Psychopharmacology. 2011; 213:465-473. [PubMed: 20945065]

Gray JM, Vecchiarelli HA, Morena M, Lee TT, Hermanson DJ, Kim AB, McLaughlin RJ, Hassan KI, Kuhne C, Wotjak CT, Deussing JM, Patel S, Hill MN. Corticotropin-releasing hormone drives anandamide hydrolysis in the amygdala to promote anxiety. The Journal of neuroscience : the official journal of the Society for Neuroscience. 2015; 35:3879-3892. [PubMed: 25740517]

Griebel G, Holmes A. 50 years of hurdles and hope in anxiolytic drug discovery. Nat Rev Drug Discov. 2013; 12:667-687. [PubMed: 23989795]

Guimaraes FS, Chiaretti TM, Graeff FG, Zuardi AW. Antianxiety effect of cannabidiol in the elevated plus-maze. Psychopharmacology. 1990; 100:558-559. [PubMed: 1969666]

Gulyas AI, Cravatt BF, Bracey MH, Dinh TP, Piomelli D, Boscia F, Freund TF. Segregation of two endocannabinoid-hydrolyzing enzymes into pre- and postsynaptic compartments in the rat hippocampus, cerebellum and amygdala. The European journal of neuroscience. 2004; 20:441458. [PubMed: 15233753]

Gunduz-Cinar O, Hill MN, McEwen BS, Holmes A. Amygdala FAAH and anandamide: mediating protection and recovery from stress. Trends in pharmacological sciences. 2013a; 34:637-644. [PubMed: 24325918] 
Gunduz-Cinar O, Macpherson KP, Cinar R, Gamble-George J, Sugden K, Williams B, Godlewski G, Ramikie TS, Gorka AX, Alapafuja SO, Nikas SP, Makriyannis A, Poulton R, Patel S, Hariri AR, Caspi A, Moffitt TE, Kunos G, Holmes A. Convergent translational evidence of a role for anandamide in amygdala-mediated fear extinction, threat processing and stress-reactivity. Molecular psychiatry. 2013b; 18:813-823. [PubMed: 22688188]

Gunduz Cinar O, Flynn S, Kaugars K, Ramikie TS, Cinar R, Kunos G, Patel S, Holmes A. Fluoxetine facilitates fear extinction through amygdala endocannabinoids. Neuropsychopharmacology : official publication of the American College of Neuropsychopharmacology in press. 2015

Gutierrez-Rodriguez A, Puente N, Elezgarai I, Ruehle S, Lutz B, Reguero L, Gerrikagoitia I, Marsicano G, Grandes P. Anatomical characterization of the cannabinoid CB1 receptor in celltype-specific mutant mouse rescue models. The Journal of comparative neurology. 2016

Haller J, Aliczki M, Pelczer KG, Spitzer K, Balogh Z, Kantor S. Effects of the fatty acid amide hydrolase inhibitor URB597 on coping behavior under challenging conditions in mice. Psychopharmacology. 2014; 231:593-601. [PubMed: 24037493]

Haller J, Barna I, Barsvari B, Gyimesi Pelczer K, Yasar S, Panlilio LV, Goldberg S. Interactions between environmental aversiveness and the anxiolytic effects of enhanced cannabinoid signaling by FAAH inhibition in rats. Psychopharmacology. 2009; 204:607-616. [PubMed: 19259645]

Han J, Kesner P, Metna-Laurent M, Duan T, Xu L, Georges F, Koehl M, Abrous DN, MendizabalZubiaga J, Grandes P, Liu Q, Bai G, Wang W, Xiong L, Ren W, Marsicano G, Zhang X. Acute cannabinoids impair working memory through astroglial CB1 receptor modulation of hippocampal LTD. Cell. 2012; 148:1039-1050. [PubMed: 22385967]

Hariri AR, Gorka A, Hyde LW, Kimak M, Halder I, Ducci F, Ferrell RE, Goldman D, Manuck SB. Divergent effects of genetic variation in endocannabinoid signaling on human threat- and rewardrelated brain function. Biological psychiatry. 2009; 66:9-16. [PubMed: 19103437]

Hartley ND, Gunduz-Cinar O, Halladay L, Bukalo O, Holmes A, Patel S. 2-arachidonoylglycerol signaling impairs short-term fear extinction. Translational psychiatry. 2016; 6:e749. [PubMed: 26926885]

Hauer D, Schelling G, Gola H, Campolongo P, Morath J, Roozendaal B, Hamuni G, Karabatsiakis A, Atsak P, Vogeser M, Kolassa IT. Plasma concentrations of endocannabinoids and related primary fatty acid amides in patients with post-traumatic stress disorder. PloS one. 2013; 8:e62741. [PubMed: 23667516]

Hauer D, Weis F, Campolongo P, Schopp M, Beiras-Fernandez A, Strewe C, Giehl M, Toth R, Kilger E, Schelling G. Glucocorticoid-endocannabinoid interaction in cardiac surgical patients: relationship to early cognitive dysfunction and late depression. Reviews in the neurosciences. 2012; 23:681-690. [PubMed: 23006898]

Hebert-Chatelain E, Desprez T, Serrat R, Bellocchio L, Soria-Gomez E, Busquets-Garcia A, Zottola AC, Delamarre A, Cannich A, Vincent P, Varilh M, Robin LM, Terral G, Garcia-Fernandez MD, Colavita M, Mazier W, Drago F, Puente N, Reguero L, Elezgarai I, Dupuy JW, Cota D, LopezRodriguez ML, Barreda-Gomez G, Massa F, Grandes P, Benard G, Marsicano G. A cannabinoid link between mitochondria and memory. Nature. 2016

Hermanson DJ, Gamble-George JC, Marnett LJ, Patel S. Substrate-selective COX-2 inhibition as a novel strategy for therapeutic endocannabinoid augmentation. Trends Pharmacol Sci. 2014; 35:358-367. [PubMed: 24845457]

Hermanson DJ, Hartley ND, Gamble-George J, Brown N, Shonesy BC, Kingsley PJ, Colbran RJ, Reese J, Marnett LJ, Patel S. Substrate-selective COX-2 inhibition decreases anxiety via endocannabinoid activation. Nature neuroscience. 2013; 16:1291-1298. [PubMed: 23912944]

Hill MN, Bierer LM, Makotkine I, Golier JA, Galea S, McEwen BS, Hillard CJ, Yehuda R. Reductions in circulating endocannabinoid levels in individuals with post-traumatic stress disorder following exposure to the World Trade Center attacks. Psychoneuroendocrinology. 2013a; 38:2952-2961. [PubMed: 24035186]

Hill MN, Ho WS, Hillard CJ, Gorzalka BB. Differential effects of the antidepressants tranylcypromine and fluoxetine on limbic cannabinoid receptor binding and endocannabinoid contents. J Neural Transm. 2008; 115:1673-1679. [PubMed: 18974922] 
Hill MN, Kumar SA, Filipski SB, Iverson M, Stuhr KL, Keith JM, Cravatt BF, Hillard CJ, Chattarji S, McEwen BS. Disruption of fatty acid amide hydrolase activity prevents the effects of chronic stress on anxiety and amygdalar microstructure. Molecular psychiatry. 2013b

Hill MN, Miller GE, Carrier EJ, Gorzalka BB, Hillard CJ. Circulating endocannabinoids and N-acyl ethanolamines are differentially regulated in major depression and following exposure to social stress. Psychoneuroendocrinology. 2009; 34:1257-1262. [PubMed: 19394765]

Hill MN, Patel S, Carrier EJ, Rademacher DJ, Ormerod BK, Hillard CJ, Gorzalka BB. Downregulation of endocannabinoid signaling in the hippocampus following chronic unpredictable stress. Neuropsychopharmacology : official publication of the American College of Neuropsychopharmacology. 2005; 30:508-515. [PubMed: 15525997]

Hirai T, Enomoto M, Kaburagi H, Sotome S, Yoshida-Tanaka K, Ukegawa M, Kuwahara H, Yamamoto M, Tajiri M, Miyata H, Hirai Y, Tominaga M, Shinomiya K, Mizusawa H, Okawa A, Yokota T. Intrathecal AAV serotype 9-mediated delivery of shRNA against TRPV1 attenuates thermal hyperalgesia in a mouse model of peripheral nerve injury. Molecular therapy : the journal of the American Society of Gene Therapy. 2014; 22:409-419. [PubMed: 24322332]

Hirvonen J, Goodwin RS, Li CT, Terry GE, Zoghbi SS, Morse C, Pike VW, Volkow ND, Huestis MA, Innis RB. Reversible and regionally selective downregulation of brain cannabinoid CB1 receptors in chronic daily cannabis smokers. Molecular psychiatry. 2012; 17:642-649. [PubMed: 21747398]

Hodes GE, Kana V, Menard C, Merad M, Russo SJ. Neuroimmune mechanisms of depression. Nature neuroscience. 2015; 18:1386-1393. [PubMed: 26404713]

Holmes A. Genetic variation in cortico-amygdala serotonin function and risk for stress-related disease. Neuroscience and biobehavioral reviews. 2008; 32:1293-1314. [PubMed: 18439676]

Hsiao YT, Yi PL, Li CL, Chang FC. Effect of cannabidiol on sleep disruption induced by the repeated combination tests consisting of open field and elevated plus-maze in rats. Neuropharmacology. 2012; 62:373-384. [PubMed: 21867717]

Hu SS, Bradshaw HB, Chen JS, Tan B, Walker JM. Prostaglandin E2 glycerol ester, an endogenous COX-2 metabolite of 2-arachidonoylglycerol, induces hyperalgesia and modulates NFkappaB activity. Br J Pharmacol. 2008; 153:1538-1549. [PubMed: 18297109]

Hudson AS, Kunstetter AC, Damasceno WC, Wanner SP. Involvement of the TRPV1 channel in the modulation of spontaneous locomotor activity, physical performance and physical exerciseinduced physiological responses. Brazilian journal of medical and biological research $=$ Revista brasileira de pesquisas medicas e biologicas. 2016; 49:e5183. [PubMed: 27191606]

Ishiguro H, Horiuchi Y, Ishikawa M, Koga M, Imai K, Suzuki Y, Morikawa M, Inada T, Watanabe Y, Takahashi M, Someya T, Ujike H, Iwata N, Ozaki N, Onaivi ES, Kunugi H, Sasaki T, Itokawa M, Arai M, Niizato K, Iritani S, Naka I, Ohashi J, Kakita A, Takahashi H, Nawa H, Arinami T. Brain cannabinoid CB2 receptor in schizophrenia. Biological psychiatry. 2010; 67:974-982. [PubMed: 19931854]

Jenniches I, Ternes S, Albayram O, Otte DM, Bach K, Bindila L, Michel K, Lutz B, Bilkei-Gorzo A, Zimmer A. Anxiety, Stress, and Fear Response in Mice With Reduced Endocannabinoid Levels. Biological psychiatry. 2016; 79:858-868. [PubMed: 25981172]

Jetly R, Heber A, Fraser G, Boisvert D. The efficacy of nabilone, a synthetic cannabinoid, in the treatment of PTSD-associated nightmares: A preliminary randomized, double-blind, placebocontrolled cross-over design study. Psychoneuroendocrinology. 2015; 51:585-588. [PubMed: 25467221]

Kathuria S, Gaetani S, Fegley D, Valino F, Duranti A, Tontini A, Mor M, Tarzia G, La Rana G, Calignano A, Giustino A, Tattoli M, Palmery M, Cuomo V, Piomelli D. Modulation of anxiety through blockade of anandamide hydrolysis. Nat Med. 2003; 9:76-81. [PubMed: 12461523]

Kaufmann WE, Worley PF, Pegg J, Bremer M, Isakson P. COX-2, a synaptically induced enzyme, is expressed by excitatory neurons at postsynaptic sites in rat cerebral cortex. Proceedings of the National Academy of Sciences of the United States of America. 1996; 93:2317-2321. [PubMed: 8637870]

Kawahara H, Drew GM, Christie MJ, Vaughan CW. Inhibition of fatty acid amide hydrolase unmasks CB1 receptor and TRPV1 channel-mediated modulation of glutamatergic synaptic transmission in midbrain periaqueductal grey. British journal of pharmacology. 2011; 163:1214-1222. [PubMed: 21175570] 
Kessler RC, Sonnega A, Bromet E, Hughes M, Nelson CB. Posttraumatic stress disorder in the National Comorbidity Survey. Arch Gen Psychiatry. 1995; 52:1048-1060. [PubMed: 7492257]

Kim J, Alger BE. Inhibition of cyclooxygenase-2 potentiates retrograde endocannabinoid effects in hippocampus. Nature neuroscience. 2004; 7:697-698. [PubMed: 15184902]

Kinsey SG, Wise LE, Ramesh D, Abdullah R, Selley DE, Cravatt BF, Lichtman AH. Repeated lowdose administration of the monoacylglycerol lipase inhibitor JZL184 retains cannabinoid receptor type 1-mediated antinociceptive and gastroprotective effects. The Journal of pharmacology and experimental therapeutics. 2013; 345:492-501. [PubMed: 23412396]

Kozak KR, Crews BC, Morrow JD, Wang LH, Ma YH, Weinander R, Jakobsson PJ, Marnett LJ. Metabolism of the endocannabinoids, 2-arachidonylglycerol and anandamide, into prostaglandin, thromboxane, and prostacyclin glycerol esters and ethanolamides. The Journal of biological chemistry. 2002; 277:44877-44885. [PubMed: 12244105]

Kozak KR, Rowlinson SW, Marnett LJ. Oxygenation of the endocannabinoid, 2-arachidonylglycerol, to glyceryl prostaglandins by cyclooxygenase-2. The Journal of biological chemistry. 2000; 275:33744-33749. [PubMed: 10931854]

Laprairie RB, Bagher AM, Kelly ME, Denovan-Wright EM. Cannabidiol is a negative allosteric modulator of the cannabinoid CB1 receptor. British journal of pharmacology. 2015; 172:4790 4805. [PubMed: 26218440]

Lee SH, Ledri M, Toth B, Marchionni I, Henstridge CM, Dudok B, Kenesei K, Barna L, Szabo SI, Renkecz T, Oberoi M, Watanabe M, Limoli CL, Horvai G, Soltesz I, Katona I. Multiple Forms of Endocannabinoid and Endovanilloid Signaling Regulate the Tonic Control of GABA Release. The Journal of neuroscience : the official journal of the Society for Neuroscience. 2015; 35:10039_ 10057. [PubMed: 26157003]

Lee TT, Hill MN, Lee FS. Developmental regulation of fear learning and anxiety behavior by endocannabinoids. Genes, brain, and behavior. 2016; 15:108-124.

Llado-Pelfort L, Santana N, Ghisi V, Artigas F, Celada P. 5-HT1A receptor agonists enhance pyramidal cell firing in prefrontal cortex through a preferential action on GABA interneurons. Cereb Cortex. 2012; 22:1487-1497. [PubMed: 21893679]

Llorente-Berzal A, Terzian AL, di Marzo V, Micale V, Viveros MP, Wotjak CT. 2-AG promotes the expression of conditioned fear via cannabinoid receptor type 1 on GABAergic neurons. Psychopharmacology. 2015; 232:2811-2825. [PubMed: 25814137]

Lomazzo E, Bindila L, Remmers F, Lerner R, Schwitter C, Hoheisel U, Lutz B. Therapeutic potential of inhibitors of endocannabinoid degradation for the treatment of stress-related hyperalgesia in an animal model of chronic pain. Neuropsychopharmacology : official publication of the American College of Neuropsychopharmacology. 2015; 40:488-501. [PubMed: 25100669]

Manji H, Kato T, Di Prospero NA, Ness S, Beal MF, Krams M, Chen G. Impaired mitochondrial function in psychiatric disorders. Nature reviews. Neuroscience. 2012; 13:293-307. [PubMed: 22510887]

Marinho AL, Vila-Verde C, Fogaca MV, Guimaraes FS. Effects of intra-infralimbic prefrontal cortex injections of cannabidiol in the modulation of emotional behaviors in rats: contribution of 5HT(1)A receptors and stressful experiences. Behavioural brain research. 2015; 286:49-56. [PubMed: 25701682]

Marsch R, Foeller E, Rammes G, Bunck M, Kossl M, Holsboer F, Zieglgansberger W, Landgraf R, Lutz B, Wotjak CT. Reduced anxiety, conditioned fear, and hippocampal long-term potentiation in transient receptor potential vanilloid type 1 receptor-deficient mice. The Journal of neuroscience : the official journal of the Society for Neuroscience. 2007; 27:832-839. [PubMed: 17251423]

Mechoulam R, Parker L. Towards a better cannabis drug. British journal of pharmacology. 2013; 170:1363-1364. [PubMed: 24024867]

Micale V, Cristino L, Tamburella A, Petrosino S, Leggio GM, Drago F, Di Marzo V. Anxiolytic effects in mice of a dual blocker of fatty acid amide hydrolase and transient receptor potential vanilloid type-1 channels. Neuropsychopharmacology : official publication of the American College of Neuropsychopharmacology. 2009; 34:593-606. [PubMed: 18580871] 
Micale V, Di Marzo V, Sulcova A, Wotjak CT, Drago F. Endocannabinoid system and mood disorders: priming a target for new therapies. Pharmacol Ther. 2013; 138:18-37. [PubMed: 23261685]

Moreira FA, Aguiar DC, Guimaraes FS. Anxiolytic-like effect of cannabidiol in the rat Vogel conflict test. Prog Neuropsychopharmacol Biol Psychiatry. 2006; 30:1466-1471. [PubMed: 16876926]

Moreira FA, Aguiar DC, Terzian AL, Guimaraes FS, Wotjak CT. Cannabinoid type 1 receptors and transient receptor potential vanilloid type 1 channels in fear and anxiety-two sides of one coin? Neuroscience. 2012; 204:186-192. [PubMed: 21906661]

Morena M, Leitl KD, Vecchiarelli HA, Gray JM, Campolongo P, Hill MN. Emotional arousal state influences the ability of amygdalar endocannabinoid signaling to modulate anxiety. Neuropharmacology. 2016a; 111:59-69. [PubMed: 27553121]

Morena M, Patel S, Bains JS, Hill MN. Neurobiological Interactions Between Stress and the Endocannabinoid System. Neuropsychopharmacology : official publication of the American College of Neuropsychopharmacology. 2016b; 41:80-102. [PubMed: 26068727]

Naidu PS, Varvel SA, Ahn K, Cravatt BF, Martin BR, Lichtman AH. Evaluation of fatty acid amide hydrolase inhibition in murine models of emotionality. Psychopharmacology. 2007; 192:61-70. [PubMed: 17279376]

Navarria A, Tamburella A, Iannotti FA, Micale V, Camillieri G, Gozzo L, Verde R, Imperatore R, Leggio GM, Drago F, Di Marzo V. The dual blocker of FAAH/TRPV1 N-arachidonoylserotonin reverses the behavioral despair induced by stress in rats and modulates the HPA-axis. Pharmacological research. 2014; 87:151-159. [PubMed: 24861565]

Neumeister A, Normandin MD, Pietrzak RH, Piomelli D, Zheng MQ, Gujarro-Anton A, Potenza MN, Bailey CR, Lin SF, Najafzadeh S, Ropchan J, Henry S, Corsi-Travali S, Carson RE, Huang Y. Elevated brain cannabinoid CB1 receptor availability in post-traumatic stress disorder: a positron emission tomography study. Molecular psychiatry. 2013; 18:1034-1040. [PubMed: 23670490]

Nyilas R, Dudok B, Urban GM, Mackie K, Watanabe M, Cravatt BF, Freund TF, Katona I. Enzymatic machinery for endocannabinoid biosynthesis associated with calcium stores in glutamatergic axon terminals. The Journal of neuroscience : the official journal of the Society for Neuroscience. 2008; 28:1058-1063. [PubMed: 18234884]

Oliveira JF, Sardinha VM, Guerra-Gomes S, Araque A, Sousa N. Do stars govern our actions? Astrocyte involvement in rodent behavior. Trends in neurosciences. 2015; 38:535-549. [PubMed: 26316036]

Onaivi ES, Green MR, Martin BR. Pharmacological characterization of cannabinoids in the elevated plus maze. The Journal of pharmacology and experimental therapeutics. 1990; 253:1002-1009. [PubMed: 2162942]

Onaivi ES, Ishiguro H, Gong JP, Patel S, Meozzi PA, Myers L, Perchuk A, Mora Z, Tagliaferro PA, Gardner E, Brusco A, Akinshola BE, Hope B, Lujilde J, Inada T, Iwasaki S, Macharia D, Teasenfitz L, Arinami T, Uhl GR. Brain neuronal CB2 cannabinoid receptors in drug abuse and depression: from mice to human subjects. PloS one. 2008; 3:e1640. [PubMed: 18286196]

Ortega-Alvaro A, Aracil-Fernandez A, Garcia-Gutierrez MS, Navarrete F, Manzanares J. Deletion of CB2 cannabinoid receptor induces schizophrenia-related behaviors in mice.

Neuropsychopharmacology : official publication of the American College of Neuropsychopharmacology. 2011; 36:1489-1504. [PubMed: 21430651]

Parolaro D. Presence and functional regulation of cannabinoid receptors in immune cells. Life sciences. 1999; 65:637-644. [PubMed: 10462064]

Patel S, Cravatt BF, Hillard CJ. Synergistic interactions between cannabinoids and environmental stress in the activation of the central amygdala. Neuropsychopharmacology : official publication of the American College of Neuropsychopharmacology. 2005; 30:497-507. [PubMed: 15280883]

Patel S, Hillard CJ. Pharmacological evaluation of cannabinoid receptor ligands in a mouse model of anxiety: further evidence for an anxiolytic role for endogenous cannabinoid signaling. The Journal of pharmacology and experimental therapeutics. 2006; 318:304-311. [PubMed: 16569753]

Puente N, Cui Y, Lassalle O, Lafourcade M, Georges F, Venance L, Grandes P, Manzoni OJ. Polymodal activation of the endocannabinoid system in the extended amygdala. Nature neuroscience. 2011; 14:1542-1547. [PubMed: 22057189] 
Puente N, Reguero L, Elezgarai I, Canduela MJ, Mendizabal-Zubiaga J, Ramos-Uriarte A, FernandezEspejo E, Grandes P. The transient receptor potential vanilloid-1 is localized at excitatory synapses in the mouse dentate gyrus. Brain structure \& function. 2015; 220:1187-1194. [PubMed: 24487914]

Racz I, Nadal X, Alferink J, Banos JE, Rehnelt J, Martin M, Pintado B, Gutierrez-Adan A, Sanguino E, Manzanares J, Zimmer A, Maldonado R. Crucial role of $\mathrm{CB}(2)$ cannabinoid receptor in the regulation of central immune responses during neuropathic pain. The Journal of neuroscience : the official journal of the Society for Neuroscience. 2008; 28:12125-12135. [PubMed: 19005077]

Rademacher DJ, Meier SE, Shi L, Ho WS, Jarrahian A, Hillard CJ. Effects of acute and repeated restraint stress on endocannabinoid content in the amygdala, ventral striatum, and medial prefrontal cortex in mice. Neuropharmacology. 2008; 54:108-116. [PubMed: 17675104]

Resstel LB, Joca SR, Moreira FA, Correa FM, Guimaraes FS. Effects of cannabidiol and diazepam on behavioral and cardiovascular responses induced by contextual conditioned fear in rats. Behav Brain Res. 2006; 172:294-298. [PubMed: 16780966]

Rock EM, Bolognini D, Limebeer CL, Cascio MG, Anavi-Goffer S, Fletcher PJ, Mechoulam R, Pertwee RG, Parker LA. Cannabidiol, a non-psychotropic component of cannabis, attenuates vomiting and nausea-like behaviour via indirect agonism of 5-HT(1A) somatodendritic autoreceptors in the dorsal raphe nucleus. British journal of pharmacology. 2012; 165:26202634. [PubMed: 21827451]

Rodriguez-Arias M, Navarrete F, Blanco-Gandia MC, Arenas MC, Aguilar MA, Bartoll-Andres A, Valverde O, Minarro J, Manzanares J. Role of CB2 receptors in social and aggressive behavior in male mice. Psychopharmacology. 2015; 232:3019-3031. [PubMed: 25921034]

Roncon CM, Biesdorf C, Coimbra NC, Audi EA, Zangrossi H Jr, Graeff FG. Cooperative regulation of anxiety and panic-related defensive behaviors in the rat periaqueductal grey matter by 5-HT1A and mu-receptors. Journal of psychopharmacology (Oxford, England). 2013; 27:1141-1148.

Rossi S, De Chiara V, Musella A, Sacchetti L, Cantarella C, Castelli M, Cavasinni F, Motta C, Studer V, Bernardi G, Cravatt BF, Maccarrone M, Usiello A, Centonze D. Preservation of striatal cannabinoid CB1 receptor function correlates with the antianxiety effects of fatty acid amide hydrolase inhibition. Molecular pharmacology. 2010; 78:260-268. [PubMed: 20424126]

Ruehle S, Remmers F, Romo-Parra H, Massa F, Wickert M, Wortge S, Haring M, Kaiser N, Marsicano G, Pape HC, Lutz B. Cannabinoid CB1 receptor in dorsal telencephalic glutamatergic neurons: distinctive sufficiency for hippocampus-dependent and amygdala-dependent synaptic and behavioral functions. The Journal of neuroscience : the official journal of the Society for Neuroscience. 2013; 33:10264-10277. [PubMed: 23785142]

Russo EB. Taming THC: potential cannabis synergy and phytocannabinoid-terpenoid entourage effects. British journal of pharmacology. 2011; 163:1344-1364. [PubMed: 21749363]

Russo EB. Beyond Cannabis: Plants and the Endocannabinoid System. Trends in pharmacological sciences. 2016; 37:594-605. [PubMed: 27179600]

Saito Y, Matsumoto M, Yanagawa Y, Hiraide S, Inoue S, Kubo Y, Shimamura K, Togashi H. Facilitation of fear extinction by the 5-HT(1A) receptor agonist tandospirone: possible involvement of dopaminergic modulation. Synapse. 2013; 67:161-170. [PubMed: 23152167]

Sang N, Zhang J, Chen C. PGE2 glycerol ester, a COX-2 oxidative metabolite of 2-arachidonoyl glycerol, modulates inhibitory synaptic transmission in mouse hippocampal neurons. J Physiol. 2006; 572:735-745. [PubMed: 16484297]

Santana N, Bortolozzi A, Serrats J, Mengod G, Artigas F. Expression of serotonin1A and serotonin2A receptors in pyramidal and GABAergic neurons of the rat prefrontal cortex. Cerebral cortex. 2004; 14:1100-1109. [PubMed: 15115744]

Savonenko A, Munoz P, Melnikova T, Wang Q, Liang X, Breyer RM, Montine TJ, Kirkwood A, Andreasson K. Impaired cognition, sensorimotor gating, and hippocampal long-term depression in mice lacking the prostaglandin E2 EP2 receptor. Experimental neurology. 2009; 217:63-73. [PubMed: 19416671]

Schiavon AP, Bonato JM, Milani H, Guimaraes FS, Weffort de Oliveira RM. Influence of single and repeated cannabidiol administration on emotional behavior and markers of cell proliferation and 
neurogenesis in non-stressed mice. Progress in neuro-psychopharmacology \& biological psychiatry. 2016; 64:27-34. [PubMed: 26187374]

Schlosburg JE, Blankman JL, Long JZ, Nomura DK, Pan B, Kinsey SG, Nguyen PT, Ramesh D, Booker L, Burston JJ, Thomas EA, Selley DE, Sim-Selley LJ, Liu QS, Lichtman AH, Cravatt BF. Chronic monoacylglycerol lipase blockade causes functional antagonism of the endocannabinoid system. Nature neuroscience. 2010; 13:1113-1119. [PubMed: 20729846]

Schlosburg JE, Kinsey SG, Ignatowska-Jankowska B, Ramesh D, Abdullah RA, Tao Q, Booker L, Long JZ, Selley DE, Cravatt BF, Lichtman AH. Prolonged monoacylglycerol lipase blockade causes equivalent cannabinoid receptor type 1 receptor-mediated adaptations in fatty acid amide hydrolase wild-type and knockout mice. The Journal of pharmacology and experimental therapeutics. 2014; 350:196-204. [PubMed: 24849924]

Sciolino NR, Zhou W, Hohmann AG. Enhancement of endocannabinoid signaling with JZL184, an inhibitor of the 2-arachidonoylglycerol hydrolyzing enzyme monoacylglycerol lipase, produces anxiolytic effects under conditions of high environmental aversiveness in rats. Pharmacological research. 2011; 64:226-234. [PubMed: 21600985]

Shonesy BC, Bluett RJ, Ramikie TS, Baldi R, Hermanson DJ, Kingsley PJ, Marnett LJ, Winder DG, Colbran RJ, Patel S. Genetic disruption of 2-arachidonoylglycerol synthesis reveals a key role for endocannabinoid signaling in anxiety modulation. Cell reports. 2014; 9:1644-1653. [PubMed: 25466252]

Sipe JC, Chiang K, Gerber AL, Beutler E, Cravatt BF. A missense mutation in human fatty acid amide hydrolase associated with problem drug use. Proceedings of the National Academy of Sciences of the United States of America. 2002; 99:8394-8399. [PubMed: 12060782]

Sipe JC, Scott TM, Murray S, Harismendy O, Simon GM, Cravatt BF, Waalen J. Biomarkers of endocannabinoid system activation in severe obesity. PloS one. 2010; 5:e8792. [PubMed: 20098695]

Slanina KA, Schweitzer P. Inhibition of cyclooxygenase-2 elicits a CB1-mediated decrease of excitatory transmission in rat CA1 hippocampus. Neuropharmacology. 2005; 49:653-659. [PubMed: 15936781]

Stein M, Breit A, Fehrentz T, Gudermann T, Trauner D. Optical control of TRPV1 channels. Angewandte Chemie (International ed. in English). 2013; 52:9845-9848. [PubMed: 23873837]

Stempel AV, Stumpf A, Zhang HY, Ozdogan T, Pannasch U, Theis AK, Otte DM, Wojtalla A, Racz I, Ponomarenko A, Xi ZX, Zimmer A, Schmitz D. Cannabinoid Type 2 Receptors Mediate a Cell Type-Specific Plasticity in the Hippocampus. Neuron. 2016; 90:795-809. [PubMed: 27133464]

Stewart SH, Pihl RO, Conrod PJ, Dongier M. Functional associations among trauma, PTSD, and substance-related disorders. Addict Behav. 1998; 23:797-812. [PubMed: 9801717]

Sumislawski JJ, Ramikie TS, Patel S. Reversible gating of endocannabinoid plasticity in the amygdala by chronic stress: a potential role for monoacylglycerol lipase inhibition in the prevention of stress-induced behavioral adaptation. Neuropsychopharmacology : official publication of the American College of Neuropsychopharmacology. 2011; 36:2750-2761. [PubMed: 21849983]

Suzuki C, Miyamoto C, Furuyashiki T, Narumiya S, Ohinata K. Central PGE2 exhibits anxiolytic-like activity via EP1 and EP4 receptors in a manner dependent on serotonin 5-HT1A, dopamine D1 and GABAA receptors. FEBS letters. 2011; 585:2357-2362. [PubMed: 21693121]

Terzian AL, Aguiar DC, Guimaraes FS, Moreira FA. Modulation of anxiety-like behaviour by Transient Receptor Potential Vanilloid Type 1 (TRPV1) channels located in the dorsolateral periaqueductal gray. European neuropsychopharmacology : the journal of the European College of Neuropsychopharmacology. 2009; 19:188-195. [PubMed: 19064314]

Thomas EA, Cravatt BF, Danielson PE, Gilula NB, Sutcliffe JG. Fatty acid amide hydrolase, the degradative enzyme for anandamide and oleamide, has selective distribution in neurons within the rat central nervous system. Journal of neuroscience research. 1997; 50:1047-1052. [PubMed: 9452020]

Tsou K, Nogueron MI, Muthian S, Sanudo-Pena MC, Hillard CJ, Deutsch DG, Walker JM. Fatty acid amide hydrolase is located preferentially in large neurons in the rat central nervous system as revealed by immunohistochemistry. Neuroscience letters. 1998; 254:137-140. [PubMed: 10214976] 
Uliana DL, Hott SC, Lisboa SF, Resstel LB. Dorsolateral periaqueductal gray matter CB1 and TRPV1 receptors exert opposite modulation on expression of contextual fear conditioning. Neuropharmacology. 2016; 103:257-269. [PubMed: 26724373]

Urquhart P, Nicolaou A, Woodward DF. Endocannabinoids and their oxygenation by cyclooxygenases, lipoxygenases and other oxygenases. Biochim Biophys Acta. 2015; 1851:366-376. [PubMed: 25543004]

Wang W, Zhang K, Yan S, Li A, Hu X, Zhang L, Liu C. Enhancement of apamin-sensitive medium afterhyperpolarization current by anandamide and its role in excitability control in cultured hippocampal neurons. Neuropharmacology. 2011; 60:901-909. [PubMed: 21272594]

Windsor MA, Hermanson DJ, Kingsley PJ, Xu S, Crews BC, Ho W, Keenan CM, Banerjee S, Sharkey KA, Marnett LJ. Substrate-Selective Inhibition of Cyclooxygenase-2: Development and Evaluation of Achiral Profen Probes. Acs Med Chem Lett. 2012; 3:759-763. [PubMed: 22984634]

Windsor MA, Valk PL, Xu S, Banerjee S, Marnett LJ. Exploring the molecular determinants of substrate-selective inhibition of cyclooxygenase-2 by lumiracoxib. Bioorg Med Chem Lett. 2013; 23:5860-5864. [PubMed: 24060487]

Xia S, Zhou Z, Leung C, Zhu Y, Pan X, Qi J, Morena M, Hill MN, Xie W, Jia Z. p21-activated kinase 1 restricts tonic endocannabinoid signaling in the hippocampus. Elife. 2016; 5

Yang H, Chen C. Cyclooxygenase-2 in synaptic signaling. Curr Pharm Des. 2008; 14:1443-1451. [PubMed: 18537667]

Yi B, Nichiporuk I, Nicolas M, Schneider S, Feuerecker M, Vassilieva G, Thieme D, Schelling G, Chouker A. Reductions in circulating endocannabinoid 2-arachidonoylglycerol levels in healthy human subjects exposed to chronic stressors. Progress in neuro-psychopharmacology \& biological psychiatry. 2016; 67:92-97. [PubMed: 26780604]

Yirmiya R, Rimmerman N, Reshef R. Depression as a microglial disease. Trends in neurosciences. 2015; 38:637-658. [PubMed: 26442697]

Zelasko S, Arnold WR, Das A. Endocannabinoid metabolism by cytochrome P450 monooxygenases. Prostaglandins Other Lipid Mediat. 2015; 116-117:112-123.

Zhang Z, Wang W, Zhong P, Liu SJ, Long JZ, Zhao L, Gao HQ, Cravatt BF, Liu QS. Blockade of 2arachidonoylglycerol hydrolysis produces antidepressant-like effects and enhances adult hippocampal neurogenesis and synaptic plasticity. Hippocampus. 2015; 25:16-26. [PubMed: 25131612]

Zhao H, Ohinata K, Yoshikawa M. Central prostaglandin $\mathrm{D}(2)$ exhibits anxiolytic-like activity via the DP(1) receptor in mice. Prostaglandins \& other lipid mediators. 2009; 88:68-72. [PubMed: 19007903]

Zhou J, Cao X, Mar AC, Ding YQ, Wang X, Li Q, Li L. Activation of postsynaptic 5-HT1A receptors improve stress adaptation. Psychopharmacology. 2014; 231:2067-2075. [PubMed: 24258351]

Zlebnik NE, Cheer JF. Beyond the CB1 Receptor: Is Cannabidiol the Answer for Disorders of Motivation? Annual review of neuroscience. 2016

Zuardi AW, Cosme RA, Graeff FG, Guimaraes FS. Effects of ipsapirone and cannabidiol on human experimental anxiety. Journal of psychopharmacology (Oxford, England). 1993; 7:82-88.

Zuardi AW, Shirakawa I, Finkelfarb E, Karniol IG. Action of cannabidiol on the anxiety and other effects produced by delta 9-THC in normal subjects. Psychopharmacology. 1982; 76:245-250. [PubMed: 6285406]

Zygmunt PM, Petersson J, Andersson DA, Chuang H, Sorgard M, Di Marzo V, Julius D, Hogestatt ED. Vanilloid receptors on sensory nerves mediate the vasodilator action of anandamide. Nature. 1999; 400:452-457. [PubMed: 10440374] 


\section{Highlights}

- The endocannabinoid (eCB) system is a therapeutic target for anxiety disorders.

- We highlight components of the eCB system that offer potential 'druggable' targets for new anxiolytic medications.

- $\quad$ Amplifying eCBs recruitment by interfering with eCB-degradation, via fatty acid amide hydrolyze (FAAH) and monoacylglycerol lipase (MAGL), is linked to reductions in anxiety-like behaviors.

- A non-canonical route to regulate $\mathrm{eCB}$ degradation and anxiety involves interfering with cyclooxygenase-2 (COX-2).

- Anxiety behavior can also be affected by targeting the CB2R subtype and the transient receptor potential vanilloid receptor type 1 (TRPV1).

- $\quad$ Cannabidiol (CBD) represents another plausible path to modulating eCBs to alleviate anxiety. 


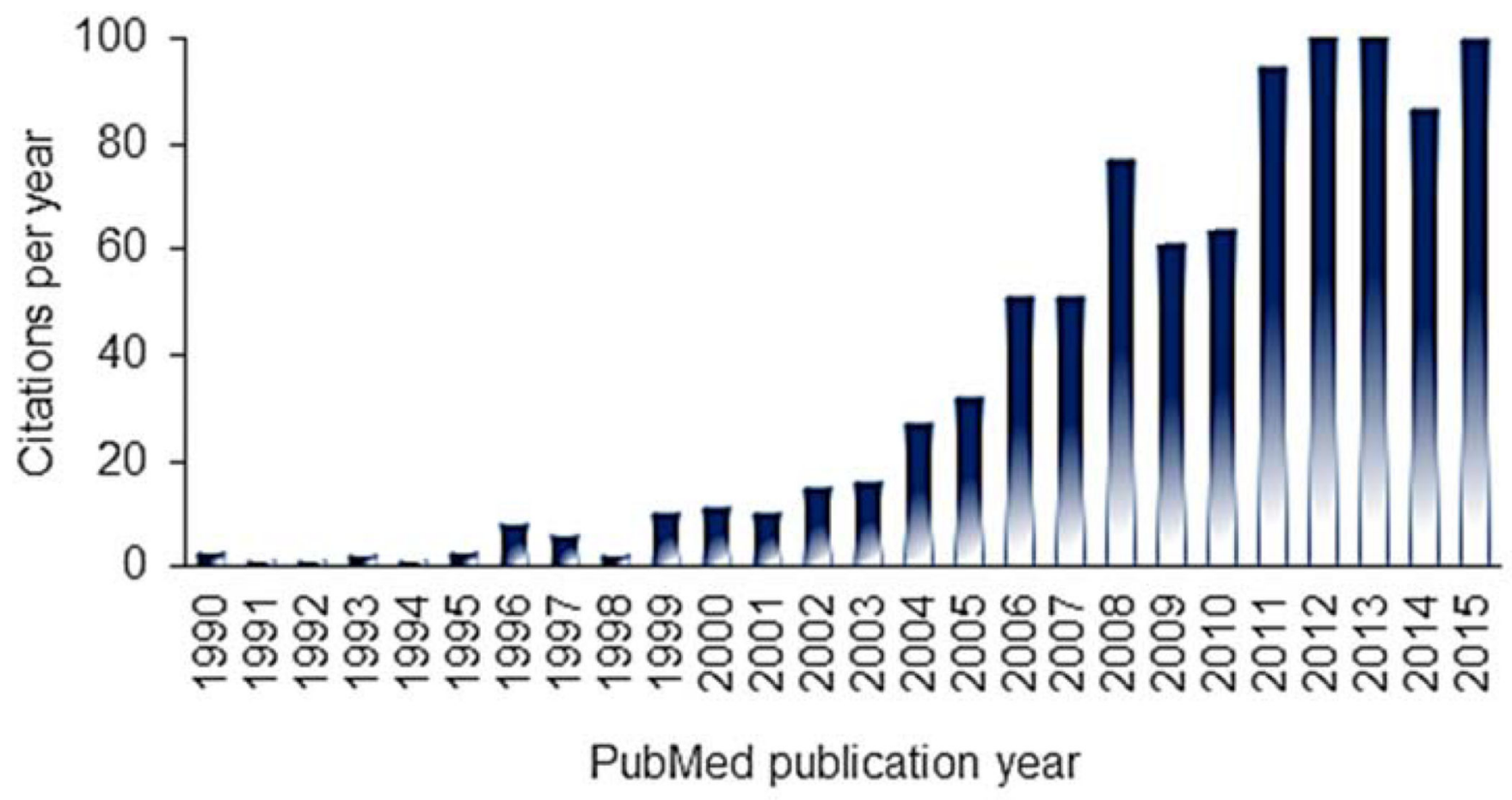

Figure 1. The burgeoning literature linking the $\mathrm{eCB}$ system and anxiety

PubMed citation results for 'cannabinoid and anxiety' from 1990 to 2015. 


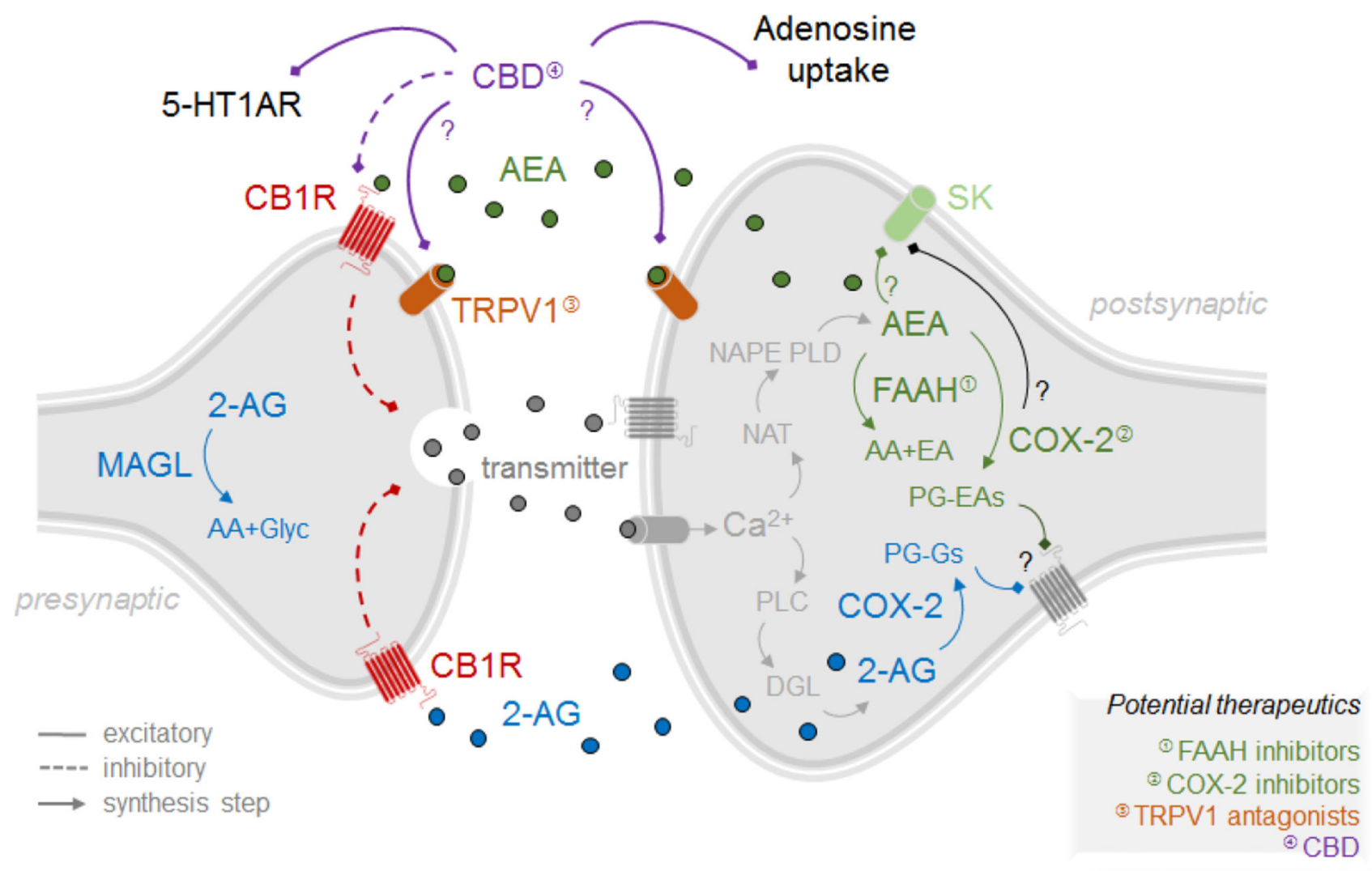

Figure 2. Potential therapeutic approaches targeting the eCB system to alleviate anxiety By increasing AEA levels, FAAH inhibitors modulate transmitter release and produce antianxiety effects, particularly under conditions of stress. COX-2 inhibitors lead to accumulation of AEA levels and can exert similar behavioral effects as FAAH inhibitors. Blockade of eCB activity at TRPV1 may produce anti-anxiety effects by modulation presynaptic and postsynaptic signaling. Finally, CBD has a diversity of anxiety-alleviating effects that have been related to activity at 5-HT1AR and adenosine update, as well as CB1R and potentially TRPV1. 5-HT1AR=5-HT1A receptor, AA=arachidonic acid,

$\mathrm{AEA}=$ anandamide, $\mathrm{AA}=\mathrm{Glyc}=\mathrm{AA}+\mathrm{Glycine}, \mathrm{CB} 1 \mathrm{R}=$ cannabinoid type 1 receptor, $\mathrm{CBD}=$ cannabidiol, DGL=diacylglycerol lipase, $\mathrm{COX}-2=$ cyclooxygenase -2 , $\mathrm{EA}=$ ethanolamide, FAAH=fatty acid amide hydrolase, MAGL=monoacylglycerol lipase, NAPE PLD $=\mathrm{N}$-acyl phosphatidylethanolamine-specific phospholipase $\mathrm{D}, \mathrm{NAT}=\mathrm{N}$ acyltransferase, PG-EA=prostaglandin ethanolamide, $\mathrm{PG}-\mathrm{Glyc}=$ prostaglandin-glycerol, $\mathrm{PLC}=$ protein lipase $\mathrm{C}, \mathrm{SK}=\mathrm{SK}$ channel, TRPV1=transient receptor potential vanilloid receptor type 1 . 


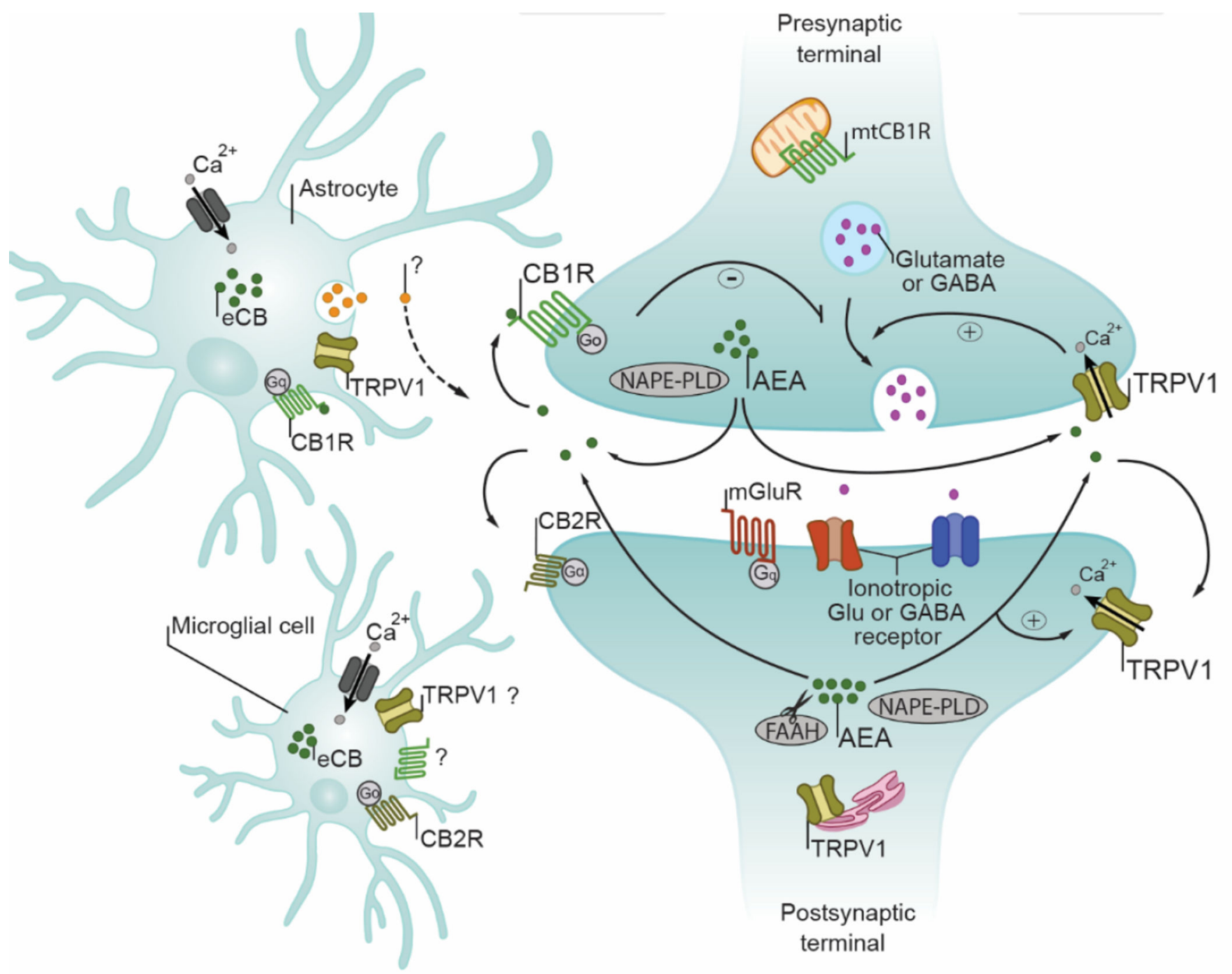

Figure 3. Role of TRPV1 in eCB signaling

AEA may serve as an endogenous ligand for both CB1R and TRPV1, with activation of $\mathrm{CB} 1 \mathrm{R}$ on presynaptic terminals leading to attenuated transmitter release. Activation of TRPV1 leads to enhanced transmitter release (if expressed presynaptically) or promotes depolarization of the postsynaptic terminal (if expressed postsynaptically). The relative roles of TRPV1 and CB1R on glutamatergic versus GABAergic terminals may depend on the concentration of the ligand. At low concentrations, endogenous and exogenous eCBs exert anxiolytic-like effects via CB1R on glutamatergic terminals (partially due to the more efficient G-protein coupling of CB1R on glutamatergic terminals). At higher concentrations, TRPV1 activation may render anxiety-related circuitry resistant to CB1R-mediated finetuning of glutamate release and eCBs may act in a paracrine manner at CB1R on GABAergic terminals to reduce inhibitory drive. The contribution of glial cells to eCBmediated anxiety-like behavior remain to be elucidated. AEA=anandamide, $\mathrm{CB} 1 \mathrm{R}=$ cannabinoid type 1 receptor, $\mathrm{CB} 1 \mathrm{R}=$ cannabinoid type 2 receptor, $\mathrm{FAAH}=$ fatty acid amide hydrolase, $\mathrm{mGluR}=$ metabotropic glutamate receptor, $\mathrm{mtCB} 1 \mathrm{R}=$ mitochondria- 
expressed cannabinoid type 1 receptor, NAPE PLD=N-acyl phosphatidylethanolaminespecific phospholipase D, TRPV1=transient receptor potential vanilloid receptor type 1 . 